
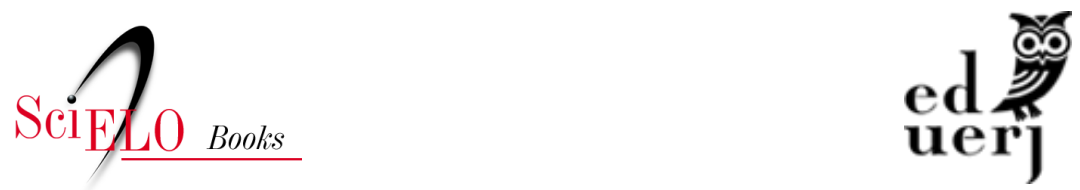

\title{
3. Unasul e política externa brasileira: a América do Sul na geopolítica mundial contemporânea
}

\author{
Tiago Nery
}

\section{SciELO Books / SciELO Livros / SciELO Libros}

NERY, T. Unasul e política externa brasileira: a América do Sul na geopolítica mundial contemporânea. In: A política externa brasileira e a UNASUL:

geopolítica e expansão do capitalismo brasileiro na América do Sul [online]. Rio de Janeiro: EDUERJ, 2021, pp. 197-265. Sociedade e política collection. ISBN: 978-65-87949-19-2. https://doi.org/10.7476/9786587949192.0005.

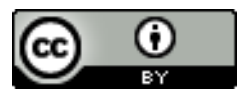

All the contents of this work, except where otherwise noted, is licensed under a Creative Commons Attribution 4.0 International license.

Todo o conteúdo deste trabalho, exceto quando houver ressalva, é publicado sob a licença Creative Commons Atribição 4.0.

Todo el contenido de esta obra, excepto donde se indique lo contrario, está bajo licencia de la licencia Creative Commons Reconocimento 4.0. 


\section{UNASUl E POLÍTICA EXTERNA BRASILEIRA: A AMÉRICA DO SUl NA GEOPOLÍTICA MUNDIAL CONTEMPORÂNEA}

Este capítulo trata das transformações geopolíticas contemporâneas, do lugar da América do Sul na nova geografia do poder mundial e do surgimento de um projeto político para a região com a criação da Unasul. A primeira seção começa com uma breve análise de algumas contribuições da geopolítica clássica. Em seguida, são analisadas as mudanças ocorridas no mundo pós-Guerra Fria, destacando-se a relevância política do conceito de "Sul" e das articulações entre os países em desenvolvimento. O BRICS representa o novo ativismo do Sul global, cuja atuação concertada procura servir de contrapeso às grandes potências. $\mathrm{O}$ declínio relativo do poder norte-americano, entretanto, não impediu que os Estados Unidos continuassem sendo a maior potência do sistema interestatal. $\mathrm{Na}$ América Latina, o cerne da política exterior norte-americana sempre foi impedir o surgimento de um polo de poder no Cone Sul capaz de questionar seu domínio hemisférico. Na primeira década do século XXI, o aumento da pressão competitiva mundial incorporou a América do Sul, cujos recursos estratégicos passaram a ser alvo da disputa entre a China e os Estados Unidos. Nesse período, o Brasil aumentou sua projeção internacional e passou a exercer crescente influência na articulação de um bloco político sul-americano.

$\mathrm{Na}$ segunda seção, procura-se analisar a política externa brasileira para a América do Sul e os diferentes regionalismos que surgiram nos últimos anos. Após um longo período marcado por 
rivalidades regionais, a diplomacia brasileira voltou-se para a América Latina no início dos anos 1960 e participou desde então das primeiras tentativas de integração regional. Com a redemocratização, a aproximação entre Brasil e Argentina adquiriu contornos econômicos e políticos que resultariam no Mercosul. Nos anos 1990, a região atravessou um período de homogeneização de suas políticas doméstica e externa, em função da hegemonia de ideias como o neoliberalismo e o regionalismo aberto, além da forte atração exercida pela proposta de integração hemisférica dos Estados Unidos. $\mathrm{Na}$ década seguinte, a mudança de prioridade da política externa estadunidense após 2001, conjugada com as consequências danosas das reformas neoliberais, abriu espaço para a vitória de coalizões progressistas na região, permitindo que os novos governos adotassem políticas exteriores mais autônomas. O novo regionalismo que emerge caracteriza-se pela diversidade, incluindo propostas liberais, autonômicas e anti-hegemônicas. Nesse cenário, a Unasul desponta como um foro político de coordenação que pode articular os distintos mecanismos integrativos. Ademais, a organização contribui para consolidar uma polaridade sul-americana autônoma no sistema internacional.

$\mathrm{Na}$ terceira e última seção, são analisadas as etapas que antecederam a constituição da Unasul, enfatizando sua estrutura institucional e o papel desempenhado pela política externa brasileira na sua consolidação. Por um lado, analisa-se a relação da organização com os demais processos de integração regional e organismos como a OEA. Por outro, destacam-se as principais divergências e afinidades entre as visões de Brasil e Venezuela durante o processo de formação do bloco. A seção procura analisar a capacidade da Unasul tornar-se uma espécie de mínimo denominador comum dos projetos de integração, além de discutir os desafios que afetam seu futuro. $\mathrm{O}$ capítulo se encerra com uma breve síntese das principais temáticas tratadas ao longo das seções. 


\subsection{A América do Sul e o Brasil na nova geopolítica mundial}

O sistema interestatal capitalista tem como característica central o processo de internacionalização, que ocorre simultaneamente ao constante fortalecimento dos seus poderes territoriais e de suas economias nacionais. Em um mundo marcado pela crescente polarização entre blocos regionais de poder, a geopolítica e os fatores geográficos - população, território, recursos naturais e localização estratégica - afetam as relações entre os Estados e a luta pela hegemonia mundial. Diante dessa realidade, os países do Sul têm como desafio disputar o espaço geopolítico com as grandes potências na tentativa de construir uma ordem global menos assimétrica. Na atual conjuntura, os países sul-americanos e o Brasil vêm direcionando seus esforços para ampliar e fortalecer a América do Sul como bloco político, de modo a garantir uma estratégia autônoma de desenvolvimento e a primazia sobre as riquezas da região.

A globalização econômica e financeira não se resume a um conjunto de fluxos geográficos, pois envolve também a maneira como esses fluxos se adaptam aos territórios. Como afirma Agnew (2005), acreditar que a geopolítica está sendo substituída por uma espécie de "cronopolítica" implica projetar o desejo utópico de um mundo sem fronteiras sobre uma realidade mundial em que a velha lógica geopolítica continua presente e operante. $\mathrm{Na}$ atual fase $\mathrm{da}$ modernidade, marcada pela aniquilação do espaço por meio do tempo, constitui um aparente paradoxo de difícil compreensão a volta do interesse pela geopolítica.

Segundo Harvey (2013), a compressão espaço-temporal, impulsionada pela revolução tecnológica, não suprimiu a geopolítica. Isso porque a transição do fordismo para a acumulação flexível não provocou uma transição paralela das atitudes e das instituições políticas. Para o geógrafo britânico, o pensamento político continuou sujeito às pressões contraditórias que surgem da integração e da diferenciação espaciais. Com efeito, o localismo e o nacionalismo 
se tornaram mais fortes devido à busca pela segurança que o lugar sempre oferece em meio às transformações causadas pela acumulação flexível. Harvey (2013, p. 275) observa que “a ressurreição da geopolítica e da fé na política carismática [...] se enquadra demasiadamente bem num mundo que é nutrido cada vez mais, em termos intelectuais e políticos, por um vasto fluxo de imagens efêmeras".

A necessidade de compreender a estrutura e os fatores que determinam as dinâmicas específicas da ordem mundial faz com que a geopolítica possa ser definida como "a política através do espaço" (Falconí, 2014, p. 125). O termo "geopolítica”, cunhado em 1899, pelo cientista político sueco Rudolf Kjellén, tornou-se desde então uma área sistemática de estudo. Kjellén, professor da Universidade de Upsala, pretendia entrosar o conhecimento geográfico com a ciência política, as relações internacionais e o direito internacional. Diferentemente da geografia política, disciplina que estuda as relações entre o espaço e a organização dos Estados, a geopolítica é um conhecimento estratégico e normativo que avalia e redesenha a própria geografia a partir de um projeto de poder específico, de caráter defensivo ou expansivo (Andrade, 1989; Fiori, 2014b; Foster, 2006).

$\mathrm{Na}$ passagem do século XIX para o XX, surgiu a geopolítica clássica como uma espécie de manifestação da rivalidade interimperialista. $\mathrm{Na}$ época, as práticas e o pensamento geopolítico eram afetados pelo engajamento direto na exploração de oportunidades comerciais e pelas perspectivas da acumulação primitiva. A divisão do mundo em esferas de influência pelas principais potências imperialistas também influenciou as nascentes correntes geopolíticas. Por isso, os teóricos da nova ciência reconheciam a relevância do domínio do espaço como uma fonte fundamental de poder político, econômico e militar. Na luta por espaços estratégicos, os primeiros formuladores geopolíticos acreditavam que a defesa do interesse nacional concedia o direito a um povo particular de dominar seu próprio entorno, assim como se a sobrevivência, a necessidade ou as 
certezas morais o impelissem a tanto - de expandir aquele interesse em nome do "destino manifesto" (Estados Unidos), da "responsabilidade do homem branco" (Inglaterra), da "missão civilizatória" (França) ou da necessidade do "espaço vital" ou "Lebensraum" (Alemanha) (Foster, 2006; Harvey, 1988, 2013). ${ }^{1}$

De maneira incorreta, costuma-se associar a geopolítica com a história da Alemanha. Isso ocorre devido à importância que as ideias de Friedrich Ratzel (1844-1904) e Karl Haushofer (18691946) tiveram - direta ou indiretamente - no desenho estratégico dos projetos expansionistas de Guilherme II (1888-1918) e de Adolf Hitler (1933-45). De fato, as bases modernas dos ensinamentos geopolíticos foram lançadas pelo geógrafo Ratzel. Apesar disso, as teorias desses dois formuladores transcenderam sua origem alemã e adquiriram novos contornos em outras potências. $\mathrm{Na}$ realidade, as teorias e as estratégias geopolíticas que alcançaram maior sucesso na história moderna foram elaboradas na Inglaterra e nos Estados Unidos (Andrade, 1989; Fiori, 2014b). ${ }^{2}$

A obra do geógrafo, economista e político britânico Halford Mackinder (1861-1947) foi de importância capital para o surgimento da geopolítica, pois ele foi responsável pela conformação da subdisciplina em seu formato atual. Ao unir diferentes fragmentos de pensamento, Mackinder conseguiu produzir uma ideia com-

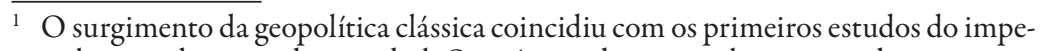
rialismo e do mercado mundial. Os teóricos do imperialismo introduziram uma imagística espacial no pensamento marxista. Autores como Bukharin, Lênin e Rosa Luxemburgo unificaram temas como a exploração, a expansão geográfica, $o$ conflito e a dominação territoriais com a teoria da acumulação do capital. Posteriormente, outros autores enfatizariam ainda mais a imagística espacial, estudando as relações assimétricas entre o centro e a periferia, ou o Primeiro e o Terceiro Mundo (Harvey, 1988).

2 Há cerca de trezentos anos, as duas grandes potências anglo-saxônicas vêm exercendo uma supremacia militar e uma hegemonia monetário-financeira sobre a maior parte do sistema político e econômico mundial. Até hoje, só existiram duas moedas de referência global: a libra e o dólar. Além disso, a Inglaterra e os Estados Unidos tiveram e seguem tendo papel decisivo na construção e na reprodução do poder mundial (Fiori, 2014b). 
preensiva. A análise do autor, que era um defensor do imperialismo britânico, partia do reconhecimento de que as fronteiras do mundo estavam fechadas, o que acarretaria uma crescente rivalidade interimperialista. A substituição da era colombina, dominada pelo poder marítimo, por uma nova era eurasiana, na qual o poder terrestre seria decisivo, impedia que as convulsões sociais se dissipassem por um espaço desconhecido, agravando os conflitos em todos os cantos do mundo (Cairo, 2008; Foster, 2006; Mackinder, 2010).

Mackinder começou a desenvolver suas ideias geopolíticas no artigo "The geographical pivot of history", publicado em 1904, na revista Geographical Review. No texto, o geógrafo britânico elaborou o modelo conhecido como "doutrina da Heartland", que marcaria a política externa inglesa do século XX. Com base na interpretação da história europeia, o autor considerava que o Estado que ocupasse o coração continental (beartland) - ou a região pivô (pivot area) -, dentro da Eurásia, seria capaz de exercer uma influência decisiva sobre a política mundial. Nesse contexto, caberia à potência marítima, o Reino Unido, uma política de equilíbrio de poder no cinturão interior (inner crescent), a periferia da Eurásia, que contorna o coração continental, já que, se os territórios dessa região fossem dominados pela potência terrestre, inevitavelmente aquela dominaria a ilha mundial (world-island), ou seja, o conjunto terrestre da Eurásia e da África, e, em última instância, o mundo. Por isso, Mackinder insistia que a política externa do Império Britânico deveria prevenir qualquer tipo de aliança ou bloco entre a Alemanha e a Rússia (Cairo, 2008; Fiori, 2014b; Foster, 2006; Mackinder, 2010). ${ }^{3}$

No modelo de Mackinder, a América Latina estava situada no âmbito de influência do Reino Unido, distante das zonas de con-

\footnotetext{
3 Segundo Mackinder (2010, p. 316), enquanto o cinturão interior (inner crescent) era formado por Alemanha, Áustria, China, Índia e Turquia, o cinturão exterior (outer crescent) era integrado por Inglaterra, Estados Unidos, Canadá, Austrália, África do Sul e Japão. Para alcançar o equilíbrio de poder, seria necessário criar um contrapeso na França em relação ao Estado pivô, a Rússia.
} 
flito principal e do centro do mundo. A região tinha inclusive menos importância do que a África subsaariana. Segundo Heriberto Cairo (2008), no modelo mackinderiano a América Latina desempenhava apenas um papel subordinado à potência europeia ou norte-americana.

Nos Estados Unidos, o formulador geopolítico mais importante da primeira metade do século XX foi o almirante Alfred Mahan (1840-1914), amigo e conselheiro do presidente Theodore Roosevelt desde antes da Guerra Hispano-Americana de 1898. A tese geopolítica fundamental de Mahan defendia que a grandeza de uma nação dependia do poder naval; foi ele o responsável por racionalizar a construção do poder naval norte-americano. Como os estadunidenses não tinham possessões coloniais nem bases militares, seus navios de guerra eram incapazes de ir além de sua própria costa. Assim, tornava-se necessário o estabelecimento de bases e depósitos de carvão para o abastecimento dos navios, de modo a apoiar o poder naval e permitir a expansão marítima e comercial dos Estados Unidos (Fiori, 2014b; Mahan, 2013; Moniz Bandeira, 2010b).

O geopolítico alemão Karl Haushofer costumava olhar para os Estados Unidos, com sua ideologia do Destino Manifesto, como o país que havia empregado com mais êxito a geopolítica dentro da sua região. Ele via a Doutrina Monroe, de 1823, que estipulava que os Estados Unidos deveriam ter hegemonia nas Américas e evitar a concorrência de qualquer poder estrangeiro, e o Corolário Roosevelt, de 1904, por meio do qual os estadunidenses reivindicavam o poder de polícia internacional no hemisfério oeste, como a maior implementação prática da geopolítica, salientando a necessidade de uma Doutrina Monroe alemã. Além disso, Haushofer e seus seguidores consideravam o pan-americanismo, cuja ideia estava bastante desenvolvida graças à Doutrina Monroe, como o agrupamento geopolítico pelo qual os Estados Unidos exerciam sua hegemonia regional. Dessa forma, tanto no modelo do cinturão exterior de Mackinder quanto no conceito das pan-regiões de Haushofer, a 
América Latina era representada como um apêndice subordinado da potência hegemônica (Cairo, 2008; Foster, 2006).

$\mathrm{Na}$ segunda metade do século XX, o autor que mais influenciou a estratégia internacional dos Estados Unidos foi o cientista político, sociólogo e jornalista de origem holando-estadunidense, Nicholas Spykman (1893-1943). Tendo como base o modelo de Mackinder, Spykman minimizou a importância do controle sobre o coração continental, argumentando que a área-chave para o domínio global era o anel continental ou Rimland. Se os Estados Unidos conseguissem controlar as bordas anfíbias da Europa, do Oriente Médio e da região costeira do Leste Asiático no Pacífico, poderiam limitar o poder da Heartland eurasiana. Assim, para conquistar e manter o poder mundial após a Segunda Guerra, Spykman recomendava que os Estados Unidos ocupassem o anel que cerca a Rússia, do Báltico até a China, aliando-se à Grã-Bretanha e à França, na Europa, e à China, na Ásia (Cairo, 2008; Fiori, 2014b; Foster, 2006).

Apesar de as opiniões de Spykman terem sido largamente difundidas nos meios políticos estadunidenses nos anos 1940, o termo "geopolítica", e mesmo o seu conceito, estava sendo evitado nos Estados Unidos devido à sua associação com a estratégia nazista de expansão mundial. Assim, embora o conceito de Rimland fornecesse o cenário intelectual da noção de containment de George Kennan, não houve, no contexto inicial da Guerra Fria, referências explícitas às ideias de Spykman. De acordo com John Bellamy Foster (2006), levaria aproximadamente um quarto de século para que o termo "geopolítica" voltasse ao discurso público.

A volta do interesse pela teoria geopolítica ocorreu nos anos 1970, na época da suposta crise da hegemonia norte-americana. Confrontado com a derrota no Vietnã e a necessidade de reestabelecer o poder dos Estados Unidos, Henry Kissinger teve atuação destacada na reintrodução do termo e na renovação das ideias geopolíticas (Cairo, 2008; Foster, 2006). Com o fim da Guerra Fria, houve quem previsse a diminuição da importância das relações de poder nas relações inter- 
nacionais. No entanto, a estratégia norte-americana de conter qualquer competidor potencial no futuro - juntamente com as guerras do Afeganistão e do Iraque -, o reerguimento da Rússia e a ascensão da China são exemplos da atualidade do pensamento geopolítico. Até mesmo a América Latina, que tinha uma importância marginal nos antigos modelos geopolíticos, passou a ser vista como uma região muito mais autônoma e estratégica. Nesse contexto, os países do Sul vêm tentando disputar o espaço geopolítico e assumir um papel cada vez mais de protagonista na ordem mundial.

Com o fim da bipolaridade no sistema internacional, muitos acreditaram no encerramento de uma era de solidariedade política que havia marcado o mundo em desenvolvimento. Parecia que a noção de Sul, juntamente com as ideias de "não alinhamento", cooperação Sul-Sul e desenvolvimento liderado pelo Estado, desapareceria com a queda do Muro de Berlim e o triunfo do pensamento neoliberal. Embora existam divergências em relação ao uso de conceitos como "Terceiro Mundo", "Sul” e "Norte", esses termos ainda conservam sua relevância explicativa e seu peso político-estratégico. Ademais, a palavra "Sul" continua funcionando para a maioria dos países em desenvolvimento como um símbolo mobilizador e expressão ideológica que abrange um conjunto de desafios que necessitam ser enfrentados por seus governos (Alden, Morphet e Vieira, 2010; Pecequilo, 2013; Vieira e Alden, 2012).

O conceito de Sul ou Terceiro Mundo nem sempre corresponde a uma referência de caráter geográfico. Trata-se de uma maneira de designar alguns países segundo um critério sociológico ou geopolítico, entretanto alguns significados da palavra Terceiro Mundo perderam o sentido com o tempo, levando à sua substituição pela dicotomia Norte-Sul. Com o colapso do bloco soviético, a noção de "não alinhamento" desapareceu. Da mesma forma, a especificidade de cada experiência colonial expôs a fragilidade do argumento de uma condição pós-colonial compartilhada. Além disso, argumentos baseados numa suposta condição de dependência econômica comum tornaram-se anacrônicos 
diante das variadas trajetórias dos países em desenvolvimento (Falconí, 2014; Randall, 2004).

Para Vicky Randall (2004), embora a categoria Terceiro Mundo seja problemática para entender e comparar a política de diferentes países, o conceito continua válido quando o objetivo é analisar os processos geopolíticos. Em primeiro lugar, o termo Terceiro Mundo ou Sul - não importa a palavra usada - ainda é útil para denunciar as assimetrias de poder e as desigualdades econômicas entre os países e as regiões. Em segundo, o conceito serve também como base de identificação simbólica, contribuindo para alinhamentos políticos e solidariedades. Por fim, a ideia de oposição Norte-Sul funciona como uma alternativa política e econômica à tese do choque de civilizações. Como argumenta Randall, conceitos como Terceiro Mundo ou Sul contribuem para reintroduzir um ponto de vista que enfatiza tanto o impacto histórico do imperialismo ocidental quanto as dimensões contemporâneas da desigualdade econômica.

A representação do Sul como um conjunto monolítico sempre foi falha, mesmo nas primeiras décadas após a descolonização. Com o crescimento de estudos especializados em países ou regiões específicas, as diferenças entre os países do Sul tornaram-se mais claras. A Índia, por exemplo, desempenhou um papel fundamental na criação e na institucionalização de uma agenda política do Sul nos anos 1950, quando foi criado o MNA, pois o país esteve na vanguarda da Conferência de Bandung de Nações Africanas e Asiáticas, em 1955. A noção de "não alinhamento", proposta por Nehru, tornou-se uma característica perene da política externa indiana. ${ }^{4}$

\footnotetext{
4 A política externa da Índia sofreu uma inflexão após os ataques de 11 de setembro de 2001, que contribuíram para aproximar Nova Deli de Washington. Com a guerra contra o Talibã e a Al-Qaeda, os Estados Unidos começaram a desconfiar do Paquistão, aliado com enorme população muçulmana e grande instabilidade política, e passaram a reconhecer o papel da Índia para a estabilidade regional. A diplomacia indiana soube explorar o aumento da sua importância estratégica no sul da Ásia, procurando adquirir o reconhecimento internacional de seu status de potência nuclear. Em julho de 2005, o governo dos Estados Unidos reconheceu formalmente a Índia como um
} 
Mesmo após introduzir reformas liberalizantes, a Índia continuou demonstrando compromisso com a agenda Sul-Sul, a exemplo do seu protagonismo no BRICS, no G-20 e no IBAS. Já a China adotou um comportamento de relativo afastamento em relação aos países em desenvolvimento. A postura de ambivalência da política externa chinesa em relação às organizações do Sul somente foi alterada após as duras críticas dos países ocidentais à repressão na Praça Tiananmen, em 1989. Depois desse episódio, o governo chinês tornou-se observador do MNA, em 1992, e reforçou sua identidade terceiro-mundista, procurando equilibrar sua parceria estratégica com os Estados Unidos com a defesa da multipolaridade e o incremento da cooperação Sul-Sul. No caso do Brasil, sua diplomacia sempre priorizou mais os aspectos econômicos da agenda Sul-Sul do que as questões políticas e de segurança, o que contribui para explicar a participação do país no G-77 e seu distanciamento do MNA (Alden, Morphet e Vieira, 2010; Pecequilo, 2013; Randall, 2004; Vieira e Alden, 2012). No entanto, a política externa do governo Lula adotou uma postura mais ativa na esfera política, promovendo articulações, como o BRICS e o IBAS, no plano mundial, e propondo iniciativas, como a Celac e a Unasul, no âmbito regional.

Um fator importante para a revitalização do Sul foi o papel assumido por alguns países - potências médias ou regionais - de liderar uma nova agenda de ativismo. $\mathrm{O}$ deslocamento mundial das estruturas de poder aponta para uma tendência de crescente multipolaridade, com a abertura de espaços para uma maior autonomia de países como Brasil, China, Índia, Rússia e África do Sul. Nos últimos anos, o BRICS tornou-se o novo polo dinâmico da economia global e passou a disputar o acesso aos diretórios do poder internacional, incorporando um elemento de natureza geopolítica a questões até então relacionadas a processos de inserção econômica. A defesa con-

legítimo Estado nuclear, visando com isso a receber o apoio indiano para algumas questões estratégicas, como a contenção das ambições nucleares do Irã e a crescente influência da China no mundo (Alden, Morphet e Vieira, 2010). 
junta dos interesses desses países coincide com a defesa dos interesses de, aproximadamente, metade da população do planeta: juntos governam cerca de 3 bilhões de pessoas, e, desde 2003, o crescimento da coalizão representou $65 \%$ da expansão do PIB mundial. Assim, a atuação concertada do BRICS pode servir de contrapeso ao poder das grandes potências (Fiori, 2014b; Souza, 2009).

Apesar de o BRICS compartilhar o status de potências regionais ou emergentes, as diferenças entre seus integrantes são ao menos tão importantes quanto os pontos que os unem. Os cinco países ocupam posição de destaque nas suas regiões pelo tamanho, pelo território, pela população e pela economia, mas são muito diferentes do ponto de vista de sua inserção internacional, geopolítica e econômica. A China, a Rússia e a Índia possuem uma situação militar absolutamente assimétrica em relação ao Brasil e à África do Sul, pois são potências atômicas, além de as duas primeiras serem membros permanentes do CSNU. Dentro do xadrez geopolítico asiático, a China e a Índia têm disputas territoriais e fronteiriças não resolvidas. Ademais, disputam zonas de influência sobrepostas. Já o Brasil e a África do Sul compartem com os gigantes asiáticos o fato de serem as maiores economias de suas regióes. Os dois países não enfrentam disputas territoriais com seus vizinhos, nem ameaças externas imediatas à sua segurança. $\mathrm{O}$ Brasil, entretanto, é mais rico e industrializado do que a África do Sul e possui mais importância e projeção em seu entorno regional (Fiori, 2014b; Lieber, 2014).

Além das diferenças mencionadas, há quem argumente que não existe apenas cooperação, mas também competição Sul-Sul. Ao lado das potências tradicionais, a China e a Índia têm intensificado suas relações com o continente africano, participando de "uma nova corrida imperialista” na África. Ademais, a atuação chinesa na América do Sul é acusada de reproduzir a clássica relação centro-periferia. Tais tensões poderão prejudicar a colaboração entre a China e os demais países em desenvolvimento no futuro (Parisot, 2013; Pecequilo, 2013).

Alguns analistas consideram que o BRICS pode contribuir para uma governança global mais híbrida, menos apoiada em princípios 
liberais, já que compartilha a rejeição à narrativa cosmopolita das potências ocidentais, defendendo o princípio clássico da soberania e mais autonomia no sistema internacional. A estrutura interna de seus membros, baseada em modelos de desenvolvimento mais estatistas, difere da existente nos principais países ocidentais. No entanto, outros autores acreditam que o BRICS não está contribuindo para uma ordem alternativa ao capitalismo ocidental. A China e a Rússia, por exemplo, teriam se convertido ao modelo consumista dos Estados Unidos, abandonando a oposição ideológica e econômica do passado. Além de que, apesar de uma maior difusão do poder no mundo, o sistema internacional ainda não está tão multilateral como se pensa (Agnew, 2005; Lieber, 2014; Parisot, 2013; Stephen, 2014).

O declínio relativo do poder norte-americano vem contribuindo para mudar a configuração geopolítica e econômica mundial, mas os Estados Unidos devem continuar como principal potência do sistema interestatal nas próximas décadas. $O$ país concentra uma combinação de elementos em todas as dimensões em que se consegue medir o poder: econômica, militar, tecnológica, geográfica e cultural. Em sua nova estratégia internacional, o governo norte-americano procura atuar nos principais tabuleiros geopolíticos mundiais, promovendo ativamente divisões regionais internas, seguindo o modelo clássico do Império Britânico. Com a Trans-Pacific Partnership (TPP) ou Parceria Transpacífico, Washington almeja afirmar sua posição política, financeira e militar no Pacífico e isolar a China. A expansão da Organização do Tratado do Atlântico Norte (OTAN) para o Leste Europeu, além de sua conversão em uma aliança ofensiva, objetiva cercar a Rússia. $\mathrm{Na}$ atual configuração geopolítica, a UE possui um papel secundário, sem capacidade de iniciativa estratégica autônoma. Na América Latina, a proliferação de tratados de livre comércio estimula as tensões entre países com governos conservadores e progressistas (Fiori, 2014b; Gordon, 2012; Lieber, 2014; Mészaros, 2003). 
Com o impasse nas negociações multilaterais de comércio, como demonstra a paralisação da Rodada Doha da OMC, a ênfase da política comercial mundial tem se deslocado na direção de acordos plurilaterais restritos a um subgrupo limitado de parceiros. No momento, os Estados Unidos estão no centro de dois mega acordos que prometem causar grande impacto nas relações comerciais mundiais: a Parceria Transpacífico (TPP) e a Transatlantic Trade and Investment Partnership (TTIP), ou Parceria Transatlântica de Comércio e Investimento. Em relação às dimensões de cada acordo, a TPP envolve doze países que respondem conjuntamente por 36\% da produção mundial, $11 \%$ da população e cerca de 33\% do comércio de mercadorias. Para os Estados Unidos, o grande atrativo da TPP é a possibilidade de utilizá-la para impor regras mais rígidas de propriedade intelectual. Por sua vez, a TTIP é uma parceria entre os Estados Unidos e a UE que responde por $46 \%$ da produção mundial e por $28 \%$ do comércio de mercadorias. Ao enfatizar a redução das barreiras não tarifárias, a Parceria Transatlântica certamente restringirá o espaço para ações regulatórias domésticas. Em resumo, tanto a TPP quanto a TTIP representam tentativas de moldar as normas do comércio internacional, contribuem para dispersar os esforços da OMC nas negociações multilaterais e constituem uma tentativa de empurrar a China para a margem das políticas de comércio (Rodrik, 2015; Wolf, 2015).

A TPP merece considerações adicionais, pois se transformou em peça central da política externa do governo Barack Obama. A "Parceria Transpacífica" busca o estabelecimento de um novo pivô asiático de contenção da China no Pacífico, possuindo dois pilares, um estratégico e outro econômico. Em relação ao primeiro pilar, a TPP foi uma reação dos Estados Unidos à incorporação pela Associação de Nações do Sudeste Asiático (Asean) da China, da Coreia do Sul e do Japão, originando a "Asean +3 " ${ }^{5}$ A criação de um bloco exclusivamente asiático,

5 A Asean foi criada em agosto de 1967 durante a Guerra do Vietnã. No contexto da Guerra Fria, o bloco tinha o propósito geopolítico de conter a expansão do comunismo vietnamita na Indochina. Inicialmente formada por Filipinas, Indonésia, 
liderado pelos chineses, deixaria Washington numa posição econômica e comercial desvantajosa na região de maior dinamismo econômico mundial. Diante de um arranjo que os exclui, os Estados Unidos procuram aproveitar o espaço da Asian-Pacific Economic Cooperation (Apec), ${ }^{6}$ com o fim de consolidar a TPP para gerar um equilíbrio com a "Asean +3" (Fiori, 2013; Pecequilo, 2013; Rodríguez, 2014).

Em relação ao pilar econômico, a TPP constitui, para o governo estadunidense, uma estratégia intermediária entre as negociações multilaterais, que se encontram paralisadas na OMC, e os tratados bilaterais de livre comércio. Trata-se de um processo plurilateral que envolve - além dos Estados Unidos - Austrália, Brunei, Canadá, Chile, Japão, Malásia, México, Nova Zelândia, Peru, Singapura e Vietnã, representando um dos maiores acordos comerciais do mundo. A extensão da TPP levanta preocupações, pois cobre praticamente todas as formas de interação econômica entre seus membros, incluindo temas como agricultura, políticas de investimento, compras governamentais, legislação ambiental e trabalhista e propriedade intelectual. Alguns críticos, com isso, temem que os Estados Unidos utilizem o acordo para impor aos parceiros sua regulação sobre patentes e propriedade intelectual. Além do mais, a TPP oferece aos países latino-america-

Malásia, Singapura e Tailândia, a Asean mudou sua natureza e se expandiu com o tempo, incorporando Brunei (1984), Vietnã (1995), Laos (1997), Mianmar (1997) e Camboja (1999). O dinamismo econômico da região no pós-Guerra Fria fez com que, a partir da sexta cúpula da Asean em 1998, a associação estabelecesse contato regular com a Coreia do Sul, a China e o Japão, levando à formação da "Asean + 3" no início do século XXI (Rodríguez, 2014).

6 A Apec foi criada em 1989 como um fórum de cooperação e concertação visando à liberalização econômica. A organização engloba países de diferentes regiões, como os Estados Unidos, a Austrália, o Chile, o Peru, a Rússia e todos os membros da Asean. No início, tratava-se de um fórum informal, sem estrutura institucional rígida ou tratados firmados, com destaque para aspectos exclusivamente econômicos. No entanto, a partir da Cúpula de Santiago, em 2004, os países da Apec vêm reconhecendo a compatibilidade entre a formalização de tratados de livre comércio e as dinâmicas de liberalização unilateral concertadas. Além disso, o fórum passou a envolver temas de cooperação em áreas tão variadas como educação, cultura e tecnologia (Rodríguez, 2014). 
nos e asiáticos acesso ao mercado norte-americano em troca de tripla condicionalidade: i) desregulamentação dos mercados financeiros; ii) adoção de normas de propriedade intelectual que deem preferência às firmas estadunidenses; e iii) permissão a empresas norte-americanas de processar diretamente esses governos por qualquer infração ao acordo (Gallagher, 2013; Gordon, 2012).

$\mathrm{O}$ aumento da pressão competitiva mundial incorporou a América do Sul, crescendo a disputa entre seus Estados, sobretudo entre o Brasil e os Estados Unidos. Desde o final do século XIX, o cerne da política externa norte-americana tem sido afirmar sua hegemonia no hemisfério ocidental, com destaque para sua área geográfica mais próxima, que é a sua zona estratégica mais importante. O principal objetivo estratégico da política externa estadunidense é impedir o surgimento de um polo de poder alternativo no Cone Sul, capaz de questionar sua hegemonia hemisférica. Por suas dimensões geográficas, demográficas e econômicas, o Brasil converte-se no único possível rival à influência dos Estados Unidos na região (Fiori, 2014b; Guimarães, 2000 e 2006).7 Como afirma Samuel Pinheiro Guimarães (2006, p. 275),

para que o Brasil e a América do Sul [...] possam ser capazes de defender efetivamente seus interesses de longo prazo em um mundo instável, violento e arbitrário, é indispensável trabalhar de forma consistente em favor da emergência de um sistema mundial multipolar no qual a América do Sul venha a constituir um dos polos e não ser apenas uma sub-região de qualquer outro polo econômico ou político.

\footnotetext{
Henry Kissinger (2001) comentou que o Brasil percebia seu relacionamento com os Estados Unidos como semelhante a dois pilares gêmeos, cabendo-lhe organizar a América Latina, enquanto os norte-americanos cumpririam a mesma tarefa na América do Norte. Ambos atuariam como duas empresas trabalhando em harmonia e articulando seus propósitos comuns. Para Luiz Alberto Moniz Bandeira (2010b), a América Latina a que Kissinger se referiu significa, em realidade, a América do Sul, pois a América do Norte, além do México, do Caribe e da América Centra, sempre foi uma área de responsabilidade dos Estados Unidos.
} 
A geografia sempre foi um condicionante central da maneira de o Brasil ver as suas relações com seus vizinhos. As condições geográficas determinam a posição do país no mundo e tornam a região uma dimensão incontornável da política externa brasileira. Com dez vizinhos contíguos, não há como ignorar a região, pois seus problemas terão necessariamente repercussão no Brasil (Simões, 2010; Souza, 2009).

Dentro da América Latina, a América do Sul apresenta maior relevância geopolítica na estratégia dos Estados Unidos devido ao enorme potencial econômico e político do subcontinente. Os doze países sul-americanos ocupam um espaço contíguo da ordem de $17.000 .000 \mathrm{~km}^{2}$, duas vezes o território dos Estados Unidos, que é de $9.631 .418 \mathrm{~km}^{2}$ (Moniz Bandeira, 2010b), portanto a geografia tem um peso decisivo na formação e no desenvolvimento da região. No entanto, grandes distâncias e obstáculos naturais, como a Bacia Amazônica e a Cordilheira dos Andes, impedem até hoje uma maior integração. Essa geografia difícil, que opõe a vertente oceânica do Atlântico à do Pacífico, além dos obstáculos mencionados, ajuda a explicar a existência de espaços vazios nas zonas fronteiriças, predispondo os países sul-americanos a uma dissociação econômica. Enquanto os Estados Unidos realizaram a junção ferroviária do Atlântico ao Pacífico ainda no século XIX, só recentemente a América do Sul passou a repensar sua estratégia de inserção internacional e de interiorização do seu desenvolvimento. Assim, os diferentes processos de integração ou de regionalismo não deveriam ser avaliados apenas por seus resultados econômicos, pois envolvem questôes geopolíticas e geoeconômicas mais complexas e globais (Costa, 2013; Dowbor, 2013; Fiori, 2014a; Souza, 2009).

A América do Sul tem um território onde estão inseridos recursos estratégicos que tendem a escassear no futuro próximo. A região possui grandes reservas de água doce e recursos minerais e energéticos que explicam sua importância estratégica dentro do sistema internacional. O estabelecimento da Década Internacional 
da Água (2005-15) pelas Nações Unidas chamou a atenção para a importância política e estratégica da água. Trata-se de um elemento vital para a sobrevivência dos organismos vivos, a garantia de níveis dignos de vida, a economia e o funcionamento dos ecossistemas. Apesar de representar uma dimensão essencial da segurança humana, 1 bilhão de pessoas ainda não têm acesso a abastecimento suficiente de água. Além disso, as características das grandes bacias hidrográficas apontam para um cenário de conflitos. Atualmente, dezenove países dependem da bacia fluvial do Danúbio, treze do Congo, onze do Nilo e nove do Amazonas, entre eles o Brasil. Dessa forma, os principais conflitos estão relacionados ao controle das fontes de água potável, demonstrando que também nesse campo as relações de poder se vinculam às de distribuição desigual dos recursos (Milani et al., 2014). A figura 1 mostra a distribuição das principais bacias hidrográficas transfronteiriças.

Figura 1 - Distribuição das principais bacias hidrográficas transfronteiriças no mundo, 2014

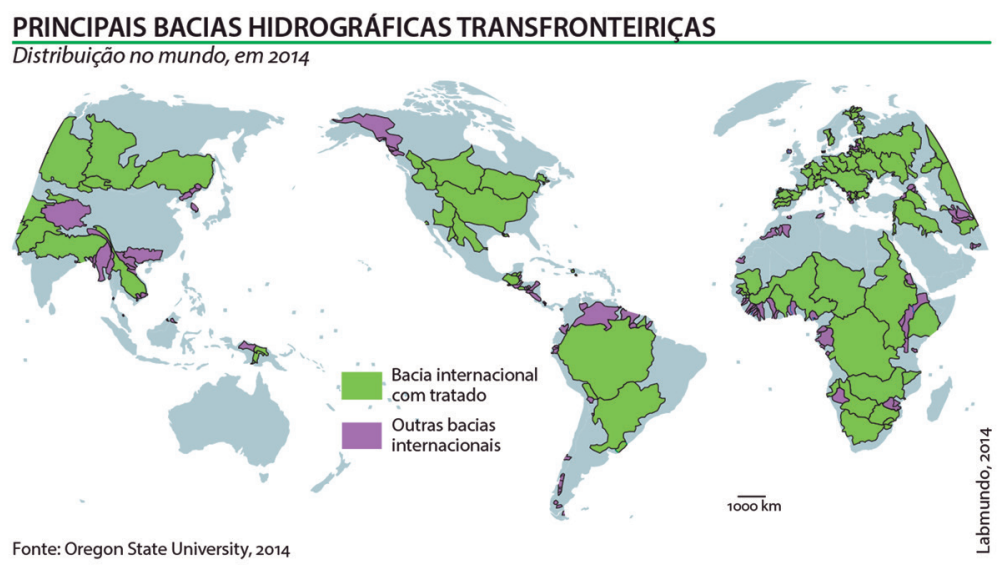

Fonte: Milani et al., 2014. 
$\mathrm{Na}$ América do Sul, as principais reservas de água, como a Bacia do Amazonas e o Aquífero Guarani, ${ }^{8}$ possuem um volume e uma capacidade de reposição que tornam o subcontinente o principal repositório de água doce do planeta. No contexto regional, o Brasil desponta como uma potência hídrica, concentrando grandes reservas de águas subterrâneas e quase $13 \%$ de toda água doce do planeta. A quantidade de água doce por habitante permite uma dotação per capita de cerca de 28.800 litros de água/dia na América do Sul, enquanto essa proporção é de 4 mil na Europa e 7 mil nos Estados Unidos. Com sua alta capacidade de reposição de águas superficiais e subterrâneas, os aquíferos podem garantir não apenas o abastecimento, como também a manutenção e a reprodução dos sistemas ecológicos e da biodiversidade. Ademais, esses recursos representam um enorme potencial de energia hidrelétrica (Bruckmann, 2012; Costa, 2013; Milani et al., 2014). Diante do quadro da geopolítica mundial da água, Monica Bruckmann (2012, p. 49) observa que "se hace necesaria una estrategia sudamericana de gestión de los recursos hídricos, con metas comunes de descontaminación y preservación de las cuencas hidrográficas, las reservas subterráneas y el manto freático".

Pela dimensão de suas reservas estratégicas, a América do Sul passou a ser revalorizada como um tabuleiro relevante da competição entre as grandes potências. Os minerais estratégicos exportados pelos países da região são demandados tanto pelos Estados Unidos quanto pela China, tendendo a acirrar a competição entre ambos por esses recursos (Fiori, 2014a; Sosa, 2013). Na geopolítica mundial dos

8 O Aquífero Guarani é um dos maiores depósitos de água doce do mundo, ocupando uma superfície total de $1.200 .000 \mathrm{~km}^{2}$, distribuídos em quatro países do Cone Sul: Brasil $\left(840.000 \mathrm{~km}^{2}\right)$; Argentina $\left(225.000 \mathrm{~km}^{2}\right)$, Paraguai $\left(58.500 \mathrm{~km}^{2}\right)$ e Uruguai $(58.500$ $\mathrm{km}^{2}$ ). Uma de suas características mais importantes é sua grande capacidade de renovação a partir das chuvas que se infiltram pelos rios, córregos e lagos (Bruckmann, 2012).

9 N. do E.: Em tradução livre, "se faz necessária uma estratégia sul-americana de gestão dos recursos hídricos, com metas compartilhadas de descontaminação e preservação das bacias hidrográficas, das reservas subterrâneas e do lençol freático.” 
minerais estratégicos, Bruckmann (2012) afirma que a disputa global entre os principais consumidores não se restringe ao âmbito comercial, pois se desdobra numa política de domínio e gestão das próprias reservas. Assim, por exemplo, a maioria dos contratos de exploração de recursos minerais entre as empresas mineradoras (seja de capital chinês, europeu ou norte-americano) e os países latino-americanos possui um marco regulatório que garante às primeiras longos períodos de operação, que variam de vinte a quarenta anos.

A partir de relatório publicado anualmente, o Departamento do Interior dos Estados Unidos avalia a relação de vulnerabilidade do país a respeito dos minerais considerados estratégicos para seu desenvolvimento. A maior parte dos recursos é importada da América Latina e está dividida em três grupos de vulnerabilidade, de acordo com o grau de dependência de importação dos Estados Unidos: "total" (99\% a 100\%); “alta” (50\% a 98\%) e; "moderada” (até 49\%). $\mathrm{Na}$ análise realizada por Bruckmann (2012) do relatório publicado em 2010, verificou-se que 7 dos 21 minerais classificados como de "total vulnerabilidade" eram importados principalmente de Brasil e México. No caso do grupo de "alta vulnerabilidade", 8 dos 17 minerais dessa categoria eram provenientes de Bolívia, Brasil, Chile, México e Peru. Por fim, em relação ao grupo de "vulnerabilidade moderada", 11 dos 25 minerais eram procedentes de Brasil, Chile, México, Peru, Trinidad e Tobago e Venezuela. A figura $2^{10}$ indica a distribuição de alguns minerais estratégicos entre os países sul-americanos.

${ }^{10}$ A figura menciona o Tratado de Cooperação Amazônica (TCA) e o Projeto Calha Norte. Com o advento das questões ambientais nos anos 1970 e os rumores de uma possível internacionalização da Amazônia, foi criado o TCA, em 1978, incluindo os seguintes países: Bolívia, Brasil, Colômbia, Equador, Guiana, Peru, Suriname e Venezuela. Os objetivos do TCA estavam voltados à preservação daquela região natural e ao uso racional dos seus recursos. Em 1998, o Brasil propôs uma emenda transformando o tratado na Organização do Tratado da Cooperação Amazônica (OTCA). Já o Projeto Calha Norte é um programa de desenvolvimento e defesa da região Norte brasileira, idealizado em 1985 e que prevê a ocupação militar de uma faixa do território nacional situada ao Norte da Calha dos rios Solimões e Amazonas. O projeto era visto como uma alternativa 
Figura 2 - Distribuição dos recursos minerais na América do Sul

RECURSOS MINERAIS NA AMÉRICA DO SUL

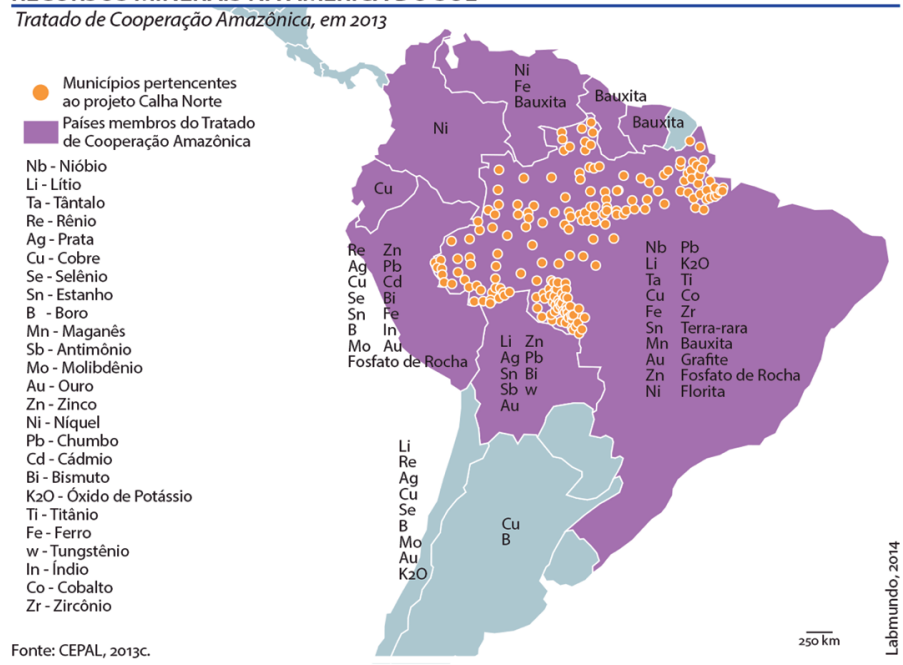

Fonte: Milani et al., 2014.

O estudo de Bruckmann (2012) identifica a dependência dos Estados Unidos em relação a alguns minerais estratégicos. Em 2005, $85 \%$ do nióbio - utilizado nas indústrias de ferro e aeroespacial - importado pelos Estados Unidos teve como fonte o Brasil, que possui $98 \%$ das reservas mundiais. Em relação ao cobre, utilizado na indústria de construção e em produtos elétricos e eletrônicos, é ainda maior a dependência dos Estados Unidos em relação à América Latina. Dados de 2009 indicavam que a região tinha $49 \%$ das reservas mundiais (Chile, 30\%; Peru, 12\%; México, 7\%) e quase $44 \%$ da produção mundial (Chile, 34\%; Peru, 8\%; México, 1,6\%). $\mathrm{Na}$ época, o consumo norte-americano de cobre dependia de $23 \%$ das importações, das quais $21 \%$ provinham da América Latina. Em

de controle regional e deveria atender aos objetivos geopolíticos brasileiros na América do Sul (Costa, 2010). 
relação ao lítio, usado em baterias recarregáveis de quase todos os dispositivos eletrônicos portáteis produzidos atualmente (câmeras fotográficas e de vídeo, computadores, telefones celulares), estima-se que mais de $90 \%$ de suas reservas se concentrem na América Latina, com destaque para a Bolívia. O consumo desse mineral pelos Estados Unidos depende de quase $50 \%$ de importações, principalmente da região. Devido ao crescimento abrupto de sua demanda, como consequência de inovações tecnológicas na produção de baterias recarregáveis, a disputa global pelo lítio deverá gerar novas tensões na América do Sul, sobretudo na região andina.

O envolvimento da China na América do Sul apoia-se em dois pilares centrais: demanda por commodities nos setores de alimento, energia e minérios; e acesso a novos mercados de exportação para seus produtos. A partir desses pilares, os chineses dividem a região em setores específicos para seus interesses: o Cone Sul, para o fornecimento de aço, ferro, petróleo e soja, além do acesso aos mercados consumidores desses países; os Andes, para a compra de minerais, petróleo e produtos pesqueiros. Em relação à dependência chinesa por produto, a maior parte da soja é fornecida por Brasil e Argentina, enquanto 80\% da farinha de peixe provém de Chile e Peru. Os investimentos no setor petroleiro e as parcerias na área envolvem Brasil, Colômbia, Equador, Peru e Venezuela. Além disso, a América Latina tem sido um espaço vital para o abastecimento de cobre, pois a China consumiu, em 2008, cerca de 30\% do cobre mundial, e necessitava multiplicar os investimentos no setor para atender à sua indústria leve. No caso do ferro, entre 1990 e 2002, a China multiplicou por sete vezes a importação desse mineral, superando o Japão e tornando-se o primeiro importador do mundo. O Brasil é o principal fornecedor do minério para o gigante asiático (Bruckmann, 2012; Ellis, 2009; Pecequilo, 2013).

O relacionamento da China com a América do Sul apresenta riscos e oportunidades. Apesar de os investimentos diretos chineses permitirem a ampliação e a modernização de setores estratégicos, que podem ter produzido uma elevação da prosperidade dos paí- 
ses sul-americanos no curto prazo, essa presença minimiza alguns efeitos negativos na relação entre as duas regiões. Alguns críticos consideram que a potência asiática estaria buscando tornar-se a principal parceira econômica individual de cada país, o que introduz uma nova relação assimétrica, afetando os fluxos intrarregionais de comércio e as complementaridades entre as nações sul-americanas. Outros analistas afirmam que Pequim age diferentemente de Washington, pois não promove intervenções violentas nos processos internos dos países da região. De fato, a potência regional asiática possui interesses majoritariamente econômicos, o que não impede os governos sul-americanos de aproveitarem sua presença para contrabalançar a habitual influência estadunidense na América Latina. Por fim, é responsabilidade dos governos sul-americanos aproveitarem a oportunidade histórica de estabelecer uma cooperação estratégica de longo prazo com a China, evitando reproduzir a velha relação centro-periferia.

A demanda dos Estados Unidos e da China por recursos naturais pode ser considerada uma oportunidade para os países sul-americanos influenciarem a formação internacional dos preços desses recursos. Isso permitiria a dinamização de suas economias, podendo levar à alteração da estrutura produtiva e à agregação de valor às exportações. Nesse sentido, a América do Sul deve se articular para aperfeiçoar a gestão e promover a industrialização de seus recursos estratégicos. Esses são alguns desafios que necessitam ser tratados por fóruns regionais, como a Unasul (Bruckmann, 2012; Falconí, 2014).

Na primeira década do século XXI, o Brasil aumentou sua projeção internacional e sua presença na América do Sul e no seu entorno, que inclui a África meridional e o Atlântico Sul. O interesse brasileiro vai além do pré-sal e de outros recursos estratégicos, pois o Atlântico Sul é uma via de comunicação e transporte fundamental entre o Brasil e a África, além de um espaço crucial para a defesa de países ribeirinhos dos dois lados do oceano. Nos últimos anos, a crescente presença brasileira, chinesa e indiana na área fez com que os Estados Unidos 
reforçassem a operação de três comandos: o Comando Militar do Sul (US SOUTHCOM), criado em 1963; o Comando Militar da África (US AFRICOM), de 2007; e a IV Frota, criada durante a Segunda Guerra Mundial, desativada em 1950 e reativada em 2008. Todos esses comandos têm o objetivo de proteger os interesses dos Estados Unidos no Atlântico Sul. Na realidade, os norte-americanos apenas reforçaram uma presença que nunca deixou de existir (Fiori, 2014b; Moniz Bandeira, 2010b; Pecequilo, 2013).

As consequências danosas das políticas de ajuste neoliberal contribuíram para criar um ambiente favorável para a vitória das oposições de centro-esquerda na América do Sul. Paralelamente às transformações no plano doméstico, o contexto internacional, marcado pelas intervenções dos Estados Unidos no Afeganistão e no Iraque, permitiu que os novos governos sul-americanos adotassem políticas exteriores mais autônomas. Kissinger (2001) percebeu essas mudanças como uma nova forma de nacionalismo que buscava uma identidade regional em oposição aos Estados Unidos. Para ele, esses governos representam o principal desafio à política hemisférica norte-americana desde a Doutrina Monroe. Ao mesmo tempo, segundo o ex-Secretário de Estado norte-americano, a ameaça comunista foi substituída pelo perigo do "populismo autoritário" de lideranças que insistem em adotar políticas externas e formas de regionalismo mais autônomas. Isso significa que os principais formuladores da política externa dos Estados Unidos continuam considerando a região uma área estratégica e estão dispostos a impedir o surgimento de um polo alternativo de poder capaz de questionar sua hegemonia no hemisfério ocidental. ${ }^{11}$

Em síntese, esta seção destacou que o mundo vem atravessando uma imensa transformação geopolítica e econômica. Nesses momentos, ampliam-se os espaços para Estados e regiões perifé-

${ }^{11}$ Em um discurso pronunciado na comissão de assuntos exteriores da Câmara dos Representantes dos Estados Unidos, em abril de 2013, o Secretário de Estado John Kerry utilizou a expressão "quintal" em referência à América Latina (Falconí, 2014). 
ricas conquistarem posições dentro da hierarquia internacional de poder e riqueza. Ademais, essas mudanças aumentam a pressão competitiva do sistema mundial e o interesse das grandes potências pelos recursos naturais dos países emergentes. Nesse contexto, a América do Sul tornou-se uma área de interesse estratégico, que desperta os interesses de chineses e norte-americanos. Por suas dimensões, o Brasil pode exercer um papel central na consolidação de um novo bloco regional capaz de projetar geopoliticamente o território. No entanto, a criação de um polo na América do Sul contraria os interesses de Washington. Assim, a consolidação de um projeto sul-americano autonômico requer a existência de coalizões políticas capazes de aproveitar as oportunidades e superar os obstáculos que surgirão no horizonte.

\subsection{A política externa brasileira para a América do Sul e os diferentes projetos de regionalismo na região}

Nos últimos trinta anos, a política externa brasileira tem procurado construir, com diferentes ênfases e sentidos, um espaço sul-americano integrado. Nesse período, os governos brasileiros buscaram romper com o padrão histórico de desunião, fragmentação e rivalidades entre os países da região. A partir dos anos 1960, ocorreram as primeiras tentativas de integração latino-americana. Com a redemocratização, houve uma aproximação com a Argentina, visando a uma integração econômica mais profunda, que resultaria no Mercosul. Nos anos 1990, o continente atravessou uma fase de homogeneização dos modelos econômicos e de integração, com a hegemonia das ideias neoliberais, a adoção do regionalismo aberto e as negociações para criação da Alca, principal projeto hemisférico dos Estados Unidos no pós-Guerra Fria. Na década seguinte, a ascensão dos governos progressistas criou um contexto regional marcado pela diversidade. Muitos países adotaram políticas econômicas heterodoxas e políticas externas autônomas em relação aos Estados 
Unidos, contribuindo para o advento de um novo regionalismo com forte conteúdo político. O Brasil teve atuação decisiva na criação de organismos como a Unasul, que é o principal expoente do regionalismo pós-liberal. Ao longo desta seção, procurar-se-á analisar a política externa brasileira para a América do Sul, a histórica oposição norte-americana à construção de um bloco de poder sul-americano $\mathrm{e}$ as diferenças entre os regionalismos latino-americanos.

Desde os processos de independência, o Brasil possui características políticas, culturais e territoriais que o distingue dos demais países hispano-americanos. O país foi capital do Império português e adotou um regime monárquico em meio a vizinhos republicanos. A sociedade e a cultura brasileiras foram conformadas como variantes da versão lusitana, enriquecidas pelas contribuições dos indígenas e dos negros. Segundo Darcy Ribeiro (1995), conquanto diferenciados em suas matrizes raciais e culturais, os brasileiros se sabem, se sentem e se comportam como uma só gente. Trata-se de uma entidade nacional que fala uma mesma língua, diferenciada apenas por sotaques regionais, menos remarcados do que os dialetos de Portugal. Ao contrário da Espanha - na Europa - ou da Guatemala - na América -, por exemplo, que são sociedades multiétnicas regidas por Estados unitários e, por isso mesmo, marcadas por conflitos interétnicos, os brasileiros se integram em uma única etnia nacional, constituindo um só povo incorporado em uma nação unificada, em um Estado uniétnico. ${ }^{12} \mathrm{~A}$ única exceção são as múl-

\footnotetext{
${ }^{12}$ Nas Américas, Ribeiro (1995) classificou três conjuntos de povos: testemunhos, transplantados e novos. Os primeiros, encontrados no México, na Guatemala e no altiplano andino, são formados por povos oriundos de altas civilizações que vivem o drama de sua dualidade cultural e o desafio de sua fusão em uma nova civilização. Já os povos transplantados reproduzem, nas Américas, os tipos humanos e a paisagem europeia. Além dos Estados Unidos e do Canadá, são transplantados os povos da Argentina e do Uruguai. Esses países receberam 4 milhões de imigrantes europeus sobre uma população de 1 milhão, soterrando a velha formação hispano-índia. Em contraste com esses dois blocos, estão os povos novos, encontrados em países onde houve uma síntese entre africanos, europeus e indígenas, como ocorreu no Brasil. Os povos novos são um novo gênero humano, mestiço na carne e no espírito. Nas
} 
tiplas microetnias tribais que não podem afetar a macroetnia em que estão contidas. Ademais, as elites brasileiras lograram manter a unidade territorial. Nesse sentido, é grande o contraste entre o bloco unitário resultante da América portuguesa e o mosaico de quadros nacionais diversos a que deu lugar a América hispânica. $\mathrm{O}$ resultado é que o Brasil possui uma área geográfica de 8.500.000 de $\mathrm{km}^{2}$, que corresponde a $48 \%$ da área total da América do Sul, e faz fronteira com dez países, totalizando mais de $15.000 \mathrm{~km}$ de extensão (Guimarães, 2006; Ribeiro, 1995).

Em decorrência das diferenças entre o Brasil e os vizinhos, o conceito de América Latina não se aplicou inicialmente ao país, e surgiu com dois significados distintos. Sob o poder de Napoleão III, Amérique Latine estava associada à doutrina do pan-latinismo, que sustentava a ideia de unidade de todos os povos de raça latina. Para seus ideólogos, a França estaria na vanguarda da raça latina, devendo liderar as demais nações a reconquistar o papel de proeminência perdido para os povos anglo-saxões e germânicos. Essas ideias acabaram justificando a intervenção no México, em 1861, quando tropas francesas estabeleceram um breve governo monárquico e colocaram Maximiliano, da Casa Habsburgo, no poder. Pouco antes, porém, em 1856, o conceito de América Latina havia sido formulado em língua espanhola pelo intelectual colombiano José Maria Torres de Caicedo. Apesar da fragmentação das repúblicas do continente, alguns intelectuais, influenciados pelo ideário de Simón Bolívar, sustentavam a ideia de uma identidade hispano-americana comum. Eles acreditavam que a "América Latina" era fundamentalmente diferente dos Estados Unidos, “a outra América”. Ademais, esses intelectuais achavam que os norte-americanos só poderiam cumprir seu Destino Manifesto avançando sobre a região. Por fim, deve-se destacar que nenhum dos dois sentidos do conceito incluía o Brasil,

palavras de Ribeiro (1995), trata-se de “[...] uma nova romanidade, uma romanidade tardia mas melhor, porque lavada em sangue índio e sangue negro”. 
pois “América Latina” era simplesmente outro nome para "América Espanhola" (Bethell, 2010; Feres Júnior, 2005). ${ }^{13}$

Apesar das diferenças identitárias, a importância da política externa brasileira para a América do Sul era percebida com clareza ao tempo do Império. As fronteiras do Estado eram ainda indefinidas e os interesses geopolíticos do Brasil se concentravam na região do Prata. De certa forma, a história da centralização do poder e da criação dos Estados nacionais na América do Sul, em especial na região geopolítica do Cone Sul e na região geoeconômica da Bacia do Prata, possui similitudes com o processo ocorrido na Europa. Dentro desse território relativamente contínuo, as guerras de independência e as guerras civis, que se sucederam entre a primeira metade do século XIX e o fim da Guerra do Paraguai (1864-70), geraram efeitos análogos àqueles produzidos nos países europeus. Após o período de conflitos e de definição de fronteiras, as rivalidades geopolíticas entre Brasil e Argentina iriam se prolongar até a segunda metade do século XX (Fiori, 2014b; Guimarães, 2006; Moniz Bandeira, 2010b).

Entre 1870 e 1930, a Argentina liderou o primeiro milagre econômico regional, tornando-se a nação sul-americana mais rica. Em 1914, o país era um dos sete mais ricos do mundo, com uma renda per capita duas vezes maior que a da Itália e 1/3 maior que a da França. Na ocasião, a estratégia geopolítica argentina visava a superar o Brasil nas disputas do Cone Sul e a impor sua hegemonia dentro do território do antigo vice-reinado do Prata. Após 1930, com o declínio da Inglaterra, que tinha uma economia complementar à da Argentina e era a principal aliada do país, as elites dirigentes argentinas perde-

\footnotetext{
${ }^{13}$ A obra de Spykman (1942) contém uma visão de duas Américas opostas e distintas. Segundo ele, as terras ao sul do Rio Grande constituíam um mundo diferente do Canadá e dos Estados Unidos. Portanto, seria algo desafortunado que as partes de fala inglesa e latina do continente fossem chamadas de América, evocando similitudes entre as duas partes que de fato não existiam. Apesar de coexistirem no mesmo hemisfério, os anglo-saxões e os latinos representariam dois mundos completamente diferentes.
} 
ram sua coesão e não conseguiram reajustar seu projeto estratégico e econômico à hegemonia dos Estados Unidos (Dosman, 2011).

$\mathrm{Na}$ mesma época, o Brasil iniciava um prolongado período de crescimento que duraria até os anos 1980, quando passou a se singularizar pela diversificação da sua matriz econômica e pelo fortalecimento do seu Estado. Embora visasse ao próprio desenvolvimento, o país acabou reestabelecendo, um século depois, por meios diplomáticos e econômicos, a hegemonia que mantivera na Bacia do Prata até 1876, quando foi superado pela Argentina. Com o aumento da disparidade estratégica, rompia-se, em favor do Brasil, o equilíbrio de poder na América do Sul. O Brasil não apenas incorporava a Bolívia, o Paraguai e o Uruguai ao seu hinterland comercial, como se projetava como uma potência regional (Fiori, 2014b; Moniz Bandeira, 2010a).

A “americanização" das relações exteriores brasileiras somente ocorreu com a República. Essa “americanização” tinha entre seus objetivos desfazer a percepção de que o Brasil era o "diferente" da América, em função das suas instituições monárquicas e do que isso significava em termo de ligações políticas e econômicas com a Europa. Nos primeiros anos de governos republicanos, a diplomacia brasileira atuou tendo em conta dois cenários: um sistema americano, liderado pelos Estados Unidos; e um subsistema sul-americano, no qual o país dispunha de uma autonomia relativa. Desse modo, o Brasil resguardava a América do Sul como sua esfera de influência e abstinha-se de qualquer envolvimento na América do Norte, Central e Caribe, por constituírem uma área de hegemonia norte-americana (Lafer, 2004; Moniz Bandeira, 2010a; Santos, 2005).

Uma das preocupações centrais da política externa dos Estados Unidos sempre foi evitar o surgimento de uma América do Sul integrada, com identidade própria, capaz de se contrapor à tradicional política estadunidense de balcanização do subcontinente. Os Estados Unidos estavam conscientes de que a América do Sul gozava de uma relativa autonomia que não era compartilhada pelos 
países centro-americanos e caribenhos. Ademais, os estadunidenses sabiam que os grandes Estados sul-americanos - Argentina, Brasil e Chile - poderiam contrabalançar seu poderio por meio de ações concertadas e de relações diplomáticas com potências de fora da região. Por isso, o Departamento de Estado procura dificultar o processo de integração, fomentando disputas internas, e busca minar iniciativas regionais que não servem aos seus desígnios. Daí a estratégia de manter afastados um do outro Brasil e Argentina, de estimular sentimentos de rivalidade e de acenar com alianças privilegiadas com cada país alternadamente, objetivando impedir a união de ambos na defesa e na promoção de seus interesses (Botelho, 2013; Guimarães, 2006; Moniz Bandeira, 2010a; Spykman, 1942).

No início do século XX, o Barão de Rio Branco propôs o Tratado do ABC, envolvendo Argentina, Brasil e Chile. Assinado em 1915 sem o caráter de aliança como pretendera Rio Branco, o tratado desagradou aos Estados Unidos porque poderia resultar na formação de um bloco no Cone Sul. No primeiro governo Vargas (193045), houve outra tentativa de aproximação entre Brasil e Argentina com o intuito de criar uma união aduaneira aberta à adesão dos países limítrofes. A decisão brasileira de entrar na Segunda Guerra Mundial reverteu a parceria, aproximou o Brasil dos Estados Unidos e renovou a rivalidade entre os dois países sul-americanos. Nos anos 1950, o governo de Juan Domingo Perón (1946-55) retomou a ideia do Pacto ABC. Apesar de simpatizar com a proposta, Vargas enfrentava uma grave crise em seu segundo mandato (1951-54), o que acabou comprometendo a iniciativa (Dosman, 2011; Moniz Bandeira, 2010a; Santos, 2005).

Em relação à última tentativa de retomada do Pacto $\mathrm{ABC}$, houve um episódio envolvendo um suposto discurso atribuído a Perón em uma entrevista concedida por João Neves da Fontoura, na qual o ex-chanceler procurava mostrar que tal fala era autêntica e exprimia a política internacional do governo peronista. Ao analisar os termos da entrevista, Hélio Jaguaribe (1954) observou 
que eles admitiam previamente duas teses completamente improcedentes. Em relação à primeira, ao afirmar que toda a divisão das Américas havia de ser contra a "América", João Neves emprestava uma unidade e homogeneidade aos países americanos que nunca existiu. Jaguaribe destaca, assim, as diferenças entre as Américas inglesa e latina, acrescentando que nem todas as formas de pan-americanismo são convenientes aos países da região. A outra tese improcedente sustentava que todas as formas de estreitar os vínculos argentino-brasileiros implicaria prejuízo ao Brasil e favorecimento à Argentina. Para refutar tal ideia, Jaguaribe argumenta que o entrosamento entre esses países constitui uma etapa inicial da integração latino-americana, ou, pelo menos, sul-americana. Apesar do caráter provocativo da entrevista, a oposição udenista e a grande imprensa endossaram as palavras do ex-chanceler e clamaram pela decretação do impeachment de Vargas. Esses fatos remetem aos dias atuais, em que a oposição de direita e os meios de comunicação criticam fortemente a política externa dos governos do PT.

A contribuição decisiva para a afirmação da identidade latino-americana ocorreu com a criação da CEPAL e as ideias originais formuladas durante sua primeira década, entre 1947-59, por uma equipe de renomados intelectuais, como Raúl Prebisch e Celso Furtado. O pensamento cepalino, articulado tacitamente com a agenda Norte-Sul, foi determinante para a "latino-americanização" da política exterior brasileira, que seria reforçada pela PEI no início dos anos 1960. A partir de então, o processo de integração latino-americano tornou-se uma sucessão de tentativas, erros, avanços e recuos. Com a redemocratização, a identidade latino-americana foi inscrita na própria Constituição Federal de 1988 (Costa, 2010; Lima, 2013; Santos, 2005).

A primeira tentativa mais ambiciosa de institucionalizar a integração ocorreu com o lançamento da Associação Latino-Americana de Livre Comércio (Alalc), em 1960. O Tratado de Montevidéu, que criou a associação, visava a constituir uma zona de livre comércio com 
o objetivo de contornar o problema da dimensão dos mercados nacionais da região, conforme diagnóstico da CEPAL. Originalmente, integraram a Alalc os seguintes países: Argentina, Brasil, Chile, México, Paraguai, Peru e Uruguai. Entre 1961 e 1967, Bolívia, Colômbia, Equador e Venezuela aderiram ao tratado. As contradições, por sua vez, entre países com diferentes graus de desenvolvimento e o crescente número de regimes militares condenaram a Alalc ao ocaso. Em 1969, porém, o surgimento do Pacto Andino foi uma resposta direta ao seu fracasso. Inicialmente, assinaram o Acordo de Cartagena que criou a organização - Bolívia, Chile, Colômbia, Equador e Peru. A Venezuela aderiu em 1973, e o Chile se retirou em 1976. Com uma proposta de integração mais ampla, o Pacto Andino objetivava constituir uma união aduaneira e foi responsável por criar algumas instituições comunitárias, como a Corporação Andina de Fomento (CAF). Nos anos 1990, após um período de crise, o Pacto Andino foi relançado como CAN. Outra iniciativa do período foi o Mercado Comum Centro-Americano (MCCA) de 1960, que, devido à ameaça representada pela Revolução Cubana, acabou recebendo maior apoio dos Estados Unidos do que a Alalc (Botelho, 2013; Furtado, 2007; Malamud, 2003; Simões, 2010). ${ }^{14}$

A posição do Brasil foi determinante para a criação da Aladi em 1980, que substituiu a Alalc. Com uma estrutura mais aberta do que sua antecessora, o novo organismo tinha como objetivo criar um mercado comum por meio de uma série de iniciativas multilaterais flexíveis e diferenciadas, segundo o nível de desenvolvimento de cada país. Como a região havia se tornado um importante mercado para a exportação de produtos manufaturados brasileiros, a Aladi aca-

\footnotetext{
${ }^{14}$ Os Estados Unidos acusaram a proposta de integração de Prebisch de violar as normas do GATT e de adotar um modelo de "regionalismo fechado" por altas tarifas que conduziriam a América Latina na direção de um protecionismo equivocado e antiempresarial. O GATT insistia que qualquer acordo comercial resultante de iniciativa da CEPAL deveria se chamar "área de livre comércio", em vez de "mercado comum”. Apesar da defesa de Prebisch de um mercado comum latino-americano, a solução de compromisso foi a Alalc (Dosman, 2011).
} 
bou contribuindo para reduzir a dependência do Brasil do mercado norte-americano. Até hoje, a Aladi funciona como uma espécie de depositária dos acordos bilaterais ou multilaterais na América Latina (Costa, 2010; Moniz Bandeira, 2010b; Simões, 2010).

Os experimentos de integração criados entre 1960 e 1980, embora não tenham sido totalmente bem-sucedidos em função dos regimes militares e da adoção generalizada do modelo substitutivo de importações, apresentavam um forte etos anti-hegemônico ou, pelo menos, a aspiração de constituir um espaço político-econômico integrado na América Latina sem a presença dos Estados Unidos (Lima, 2013). O final do período desenvolvimentista, que coincidiu com a transição democrática, foi sucedido por uma década marcada por profunda crise econômica e social. Todavia, foi nesse contexto tumultuado que ocorreu uma nova aproximação entre Brasil e Argentina que resultaria na criação do Mercosul.

A cooperação entre Brasil e Argentina começou ainda no final do regime militar. Em 1979, os dois países, juntamente com o Paraguai, assinaram o Acordo de Cooperação para o aproveitamento hidrelétrico e a regulação do uso do rio Paraná, que autorizou a construção das usinas de Itaipu e Corpus. Em 1980, brasileiros e argentinos celebraram o Acordo de Cooperação para o Desenvolvimento e Aplicação dos Usos Pacíficos da Energia Nuclear, colocando fim às tensões militares entre os dois países. Com a ascensão dos presidentes civis José Sarney e Raúl Alfonsín, a aproximação entre Brasil e Argentina ganhou novo impulso com a assinatura da Ata de Iguaçu, em 1985. Os dois líderes tinham consciência de que se tratava de um processo político e necessário à defesa dos interesses das duas nações em um sistema internacional cada vez mais agressivo e competitivo (Chaves, 2013; Costa, 2010; Guimarães, 2006; Martins, 2011).

O modelo de integração bilateral baseado no Programa de Integração e Cooperação Econômica (PICE), de 1986, e no Tratado de Integração, Cooperação e Desenvolvimento, de 1988, previa a constituição de um espaço econômico comum por meio de um 
programa gradual e equilibrado de abertura comercial e de criação de mecanismos de desenvolvimento industrial e tecnológico entre Brasil e Argentina (Guimarães, 2006; Moniz Bandeira, 2010a). No entanto, alterações profundas nos contextos nacional e internacional modificariam os rumos do processo de integração nos anos 1990.

Com a vitória de Fernando Collor e de Carlos Menem, as coalizões liberal-conservadoras adaptaram os objetivos do Tratado de 1988 às políticas de abertura econômica, visando a acelerar o ritmo da liberalização comercial. Em 1991, o Tratado de Assunção incorporou o Paraguai e o Uruguai ao eixo bilateral Brasil-Argentina, criando o Mercosul. O novo bloco abandonou os aspectos desenvolvimentistas e passou a funcionar como um esquema de redução automática de barreiras comerciais. Criou-se uma zona de livre comércio e reduziram-se os prazos para a formação da união aduaneira. O Mercosul, dessa forma, passou a funcionar como um modo de lock in, servindo para acelerar as políticas de ajuste estrutural em cada um dos sócios. Além disso, o Tratado de Assunção sequer mencionava o conceito de assimetria, limitando-se a estabelecer prazos de liberalização distintos para os países menores (Granja, 2011; Guimarães, 2006; Lima, 2013; Moniz Bandeira, 2010a). ${ }^{15}$

No plano internacional, a década de 1990 foi marcada pela prevalência da iniciativa política dos Estados Unidos e pela reafirmação de sua posição hegemônica no continente. Com o fim da Guerra Fria e o avanço do receituário neoliberal na América Latina, os processos de integração, portanto, convergiram sob a liderança norte-americana. $\mathrm{O}$ primeiro passo foi o acordo de livre comércio entre os Estados Unidos e o Canadá, logo estendido ao México, com a formação do Nafta. Em seguida, surgiu a proposta de integração hemisférica em torno da Alca, que permitiria aos Estados Unidos

${ }^{15} \mathrm{O}$ tratamento das assimetrias intrabloco só passaria a ser um tema relevante com a ascensão dos governos progressistas de Lula e Kirchner. Em 2004, foi criado o Focem, um fundo que tem como principal objetivo a redução das assimetrias estruturais do Mercosul (Granja, 2011). 
não apenas expandir seu domínio sobre os mercados sul-americanos, mas também alinhar os Estados do subcontinente às suas diretrizes políticas e ao modelo liberal de democracia (Lima, 2013; Moniz Bandeira, 2010a; Pecequilo, 2013).

O desenvolvimento do Mercosul não convinha aos propósitos políticos e econômicos dos Estados Unidos, visto que, apesar da grande assimetria, o Brasil era o único país em condições de rivalizar com a potência norte-americana. A propósito, o Brasil, desempenhando funções geopolíticas e geoeconômicas, e o Mercosul, como polo de gravitação, eram as únicas forças capazes de travar o avanço da Alca e de articular um projeto alternativo de integração (Moniz Bandeira, 2010a; Rocha Valencia e Morales Ruvalcaba, 2013). Ao analisar as negociações hemisféricas, Kissinger (2001) ressaltou que os Estados Unidos não tinham nenhum motivo para se opor ao Mercosul, desde que o bloco atuasse como um parceiro do Nafta no processo de criação da Alca. Em tais circunstâncias, a diplomacia brasileira deixou de buscar a integração de toda a América Latina e passou a enfatizar o conceito de América do Sul.

O processo de negociação da Alca e a adesão do México ao Nafta contribuíram decisivamente para a retomada do conceito de América do Sul, sobrepondo a geografia à ideia de latinidade. Ao retomar esse conceito, o Brasil tacitamente reconhecia que era incapaz de exercer qualquer influência significativa no conjunto da América Latina. Para alguns analistas, a ênfase no subcontinente sul-americano tem menos relação com uma suposta identidade regional do que com um cálculo instrumental baseado em considerações de poder e autonomia. A busca pela cooperação sul-americana está relacionada com o peso do tema da autonomia na ação externa brasileira. Nesse sentido, a região poderia tanto aumentar a capacidade nacional de enfrentar os desafios da globalização quanto funcionar como uma plataforma de projeção do poder do Brasil. Para outros críticos, questões identitárias e geopolíticas possuem maior importância. O conceito de América Latina seria genérico e 
teria perdido sentido quando a política externa mexicana renunciou a qualquer expectativa autonomista. Ao circunscrever o processo de integração à América do Sul, o Brasil resgatou um conceito essencialmente geopolítico e geoestratégico, em virtude das características econômicas, políticas e culturais que distinguem a sub-região das demais áreas (Costa, 2010; Malamud, 2009; Martins, 2011; Moniz Bandeira, 2010b; Souza, 2009; Spektor, 2011; Vigevani e Ramanzini Júnior, 2014). Em conformidade com essa perspectiva, Samuel Pinheiro Guimarães (2000, p. 146) afirma que "a América do Sul é a circunstância inevitável, histórica e geográfica do Estado e da sociedade brasileira”.

A partir do momento que a diplomacia brasileira passou a priorizar o conceito de América do Sul, a primeira iniciativa concreta de formar um bloco sub-regional foi a proposta da Alcsa durante o governo Itamar Franco. O objetivo da Alcsa era constituir um contrapeso ao Nafta, mediante a formação de um espaço econômico sul-americano que tinha como núcleo o Mercosul. Durante o primeiro mandato do presidente Fernando Henrique Cardoso, a ideia da Alcsa foi progressivamente esquecida, abandonando-se o projeto sul-americano mais amplo. As difíceis negociações da Alca, a não reciprocidade dos países desenvolvidos em relação às demandas brasileiras e o lançamento do Plano Colômbia ${ }^{16}$ fizeram com que a noção de América do Sul voltasse a ser um conceito-chave no final

\footnotetext{
${ }^{16}$ O Congresso dos Estados Unidos aprovou o Plano Colômbia em 2000, no final do governo Clinton (1993-2001). Criado juntamente com projetos de desenvolvimento econômico e social, o plano foi concebido segundo uma lógica militar e enquadrava o longo conflito colombiano exclusivamente em sua dimensão armada. A maior parte dos US\$1,3 bilhão foi destinada à compra de material bélico pelo governo colombiano. No entanto, o Plano Colômbia não visava apenas a combater o narcotráfico e as guerrilhas. Na realidade, ele possuía nítidos objetivos políticos e estratégicos. Além de ricas jazidas de petróleo, existia, na Amazônia colombiana, cuja biodiversidade só era inferior à do Brasil, abundância de recursos hídricos e florestais, que atraíam investimentos estrangeiros e constituíam recursos estratégicos para os estadunidenses. Ademais, o plano encobria uma estratégia de guerra com vistas à instalação de uma rede de bases militares, como as de Manta, no Equador, Beatrix, em Aruba, e Hato, em Curaçao (Moniz Bandeira, 2010a).
} 
do governo Fernando Henrique. Com as Reuniões Presidenciais de Brasília, em 2000, e de Guayaquil, em 2002, a diplomacia brasileira reafirmou seu interesse em construir um espaço sul-americano integrado. Nesses encontros, entretanto, ainda não estava presente uma visão política da América do Sul. Com o governo Lula, a região passou a ser apresentada como a maior prioridade da política externa brasileira. A visão autonomista de sua política exterior teve entre seus objetivos fortalecer os mecanismos de cooperação regional e articular um espaço econômico e político sul-americano. A concretização desse esforço de afirmação da autonomia regional viria com a criação da Unasul em 2008 (Moniz Bandeira, 2010a; Santos, 2005; Simões, 2010; Vigevani e Ramanzini Júnior, 2014).

Nos anos 2000, a América Latina deixou para trás a homogeneização forçada da década anterior, quando a região teve de se submeter ao ajuste estrutural e às condicionalidades impostas pela crise da dívida externa. Os resultados negativos das políticas neoliberais, ao permitirem o avanço das forças de esquerda, contribuíram para reduzir a influência dos Estados Unidos na região. No início do novo milênio, os cenários homogeneizantes tiveram de ser revistos diante da crescente complexificação do subcontinente. Houve um reordenamento do espaço regional que resultou em diferentes modelos de integração, formatos de democracia e opções de política externa. A heterogeneidade das experiências nacionais levou a variações nas esferas política e econômica, sobretudo na América do Sul (Botelho, 2013; Lima, 2013).

Algumas mudanças no contexto mundial contribuíram para a emergência de um novo mapa geopolítico regional. A partir de 11 de setembro de 2001, os Estados Unidos passaram a priorizar o Oriente Médio como área de atuação estratégica. A chamada "guerra contra o terror" colocou a América do Sul em um teatro estratégico secundário e abriu espaço para atuações mais independentes por parte dos governos de Brasil e Venezuela. Ademais, o fracasso da Alca reforçou a irrelevância política do conceito de hemisfério ocidental 
e acentuou a crise do sistema interamericano. ${ }^{17}$ Isso resultou em um aumento da margem de manobra dos países da região, que colocaram em prática instrumentos próprios talhados para suas necessidades específicas. Iniciativas como a Aliança Bolivariana para os Povos da Nossa América - Tratado de Comércio dos Povos (Alba-TCP), a Celac e a Unasul constituem políticas regionais transformadoras. Essas organizações têm em comum o fato de partirem dos próprios países latino-americanos, inserindo-se no movimento mais geral visando uma ordem internacional multipolar, que procura articular um espaço político regional a partir do fortalecimento de mecanismos de cooperação (Ayerbe, 2014; Lima, 2013; Pecequilo, 2013; Serbin, 2009 e 2013).

A figura 3 mostra sinteticamente os diversos esquemas integrativos e as organizações regionais que surgiram nas Américas entre 1945 e 2014.

${ }^{17} \mathrm{O}$ sistema interamericano tem como principais instituições a OEA e o Tratado Interamericano de Assistência Recíproca (TIAR), criados no pós-Segunda Guerra, no auge da hegemonia dos Estados Unidos na região. A Guerra das Malvinas, entre a Argentina e a Inglaterra em 1982, e a redemocratização latino-americana aceleraram a crise desse sistema regional, que ainda teria um momento de euforia com a proposta da Alca nos anos 1990. Nos últimos anos, a continuidade da abordagem hemisférica da política externa estadunidense perdeu consenso, quando despontaram análises vislumbrando um cenário pós-Doutrina Monroe, que priorizaria convergências sub-regionais ou bilaterais (Ayerbe, 2014; Lima, 2013; Pecequilo, 2013). 
Figura 3 - Organismos de integração regional nas Américas, fundados entre 1945 e 2014

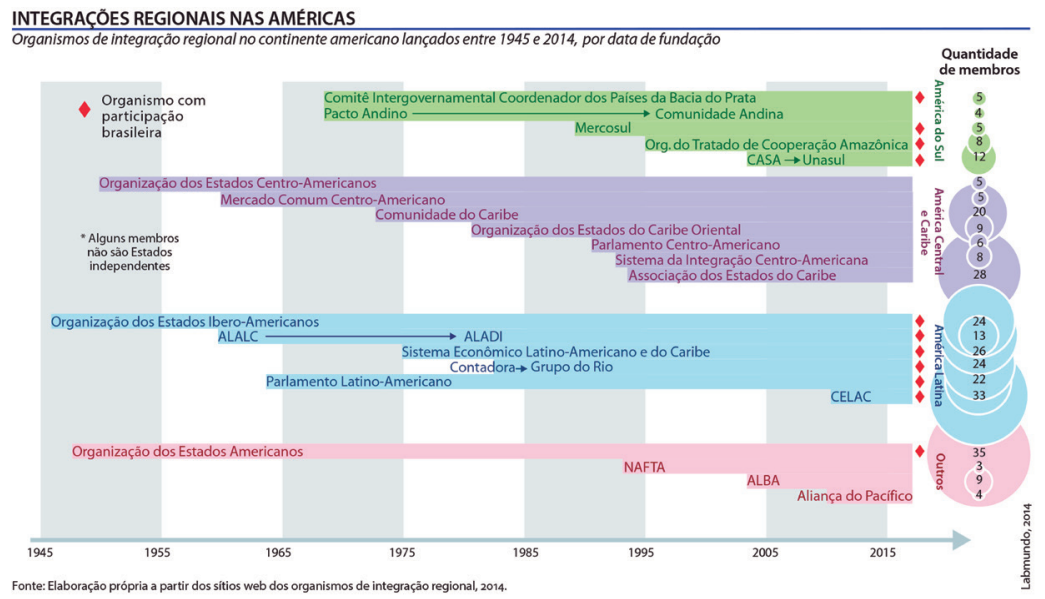

Fonte : Milani et al, 2014.

Antes de analisar as diferentes organizações surgidas nos últimos anos, é preciso tecer algumas observações acerca das particularidades dos processos de regionalização do subcontinente. Inicialmente, faz-se necessário ajustar as lentes conceituais à realidade da região e superar os modelos teleológicos de integração. A alegada experiência frustrada da integração latino-americana ou sul-americana decorre do fato de muitos especialistas adotarem o modelo idealizado e etapista europeu. No entanto, as duas regiões seguiram caminhos bastante diferentes, mostrando que as teorias orientadas para a UE são insuficientes para explicar a regionalização na América do Sul. Dessa maneira, a análise dos esquemas de integração requer a necessidade de perceber as ferramentas que podem ter sido úteis para o caso europeu, mas nem por isso são adequadas à compreensão do processo que ocorre ao Sul. Assim, conhecer as especificidades é o primeiro passo para uma teorização não abstrata, mas contextua- 
lizada da integração sul-americana (Lima, 2013; Malamud, 2003; Observatório Político Sul-Americano, 2012; Sarti, 2011). ${ }^{18}$

No esforço analítico e prático de estabelecer as bases conceituais do regionalismo sul-americano, Maria Regina Soares de Lima (2013) reconhece que o primeiro passo é arquivar o argumento teleológico do modelo europeu e, em seguida, propõe a distinção entre processos de integração e de regionalização. De um lado, o conceito de integração implica redução ou eliminação de restrições à livre circulação de bens, capitais, serviços e pessoas, além de envolver, em alguns casos, a delegação de soberania a uma autoridade supranacional. De outro, o regionalismo significa processos de cooperação em diversas áreas - política, econômica, energética, militar, técnica -, refletindo prioridades de política externa e destacando a dimensão geoestratégica. $\mathrm{O}$ regionalismo possui ainda objetivos menos ambiciosos, por ser uma dinâmica basicamente intergovernamental, envolvendo graus variados de coordenação de políticas governamentais e quase nenhuma delegação de soberania. Além dessas diferenças, Ingrid Sarti (2011) tem razão quando afirma que a integração, o regionalismo e as relações internacionais de cooperação nunca são questôes meramente técnicas, pois sempre estão sujeitas às determinações das disputas de poder e condicionadas às variações políticas representadas nos governos.

De uma concepção integracionista que privilegiava a questão comercial, os governos sul-americanos de centro-esquerda passaram a dar preferência a processos mais cooperativos. O caráter apolítico

\footnotetext{
${ }_{18}$ A integração no Cone Sul, seja no Mercosul ou na Unasul, destoa das teorias desenvolvidas por neofuncionalistas e liberal-intergovernamentalistas. Para os primeiros, a integração possui um mecanismo central de transbordamento (spill over) voltado à atenuação do poder nacional, direcionado ao favorecimento da supranacionalidade. O processo se inicia com temas comerciais até atingir a integração política. Para os intergovernamentalistas, a condição necessária para a integração é a interdependência econômica. A integração resulta da combinação dos interesses nacionais, ou seja, do cálculo dos Estados e de sua capacidade de atender os diferentes atores sociais (Botelho, 2013; Malamud, 2003; Saraiva, 2010; Vigevani e Ramanzini Júnior, 2014).
} 
dos velhos mecanismos foi substituído por uma repolitização da agenda, deslocando a ênfase de temas comerciais e econômicos para assuntos políticos. O novo regionalismo, como processo dinâmico e não estático, reconhece a importância do comércio, mas vai além dessa dimensão. Trata-se de um fenômeno alternativo à integração comercial tradicional, pois agrega fatores estratégicos, como segurança, solução de conflitos, defesa dos direitos humanos, vigência da democracia, desenvolvimento socioeconômico integral e equitativo, proteção do meio ambiente e integração física e energética. Assim, os governos sul-americanos vêm propondo modelos de regionalismo que pretendem alterar o paradigma de integração econômico tradicional, de caráter assimétrico e insuficiente. Apesar de recente, a Unasul tem sido o mais representativo expoente do novo regionalismo (Carrión Mena, 2013; Saraiva, 2010; Serbin, 2013).

Diante da sobreposição dos esquemas integrativos, alguns críticos consideram que a América Latina está condenada a reinventar siglas periodicamente, evitando assim entrar nos terrenos mais conflitivos que giram em torno do aprofundamento dos mecanismos existentes. Todavia, esses especialistas parecem esquecer que a supranacionalidade da UE tem sido apontada como um dos fatores responsáveis por apagar os últimos vestígios do pacto social que esteve na origem do projeto europeu. Além disso, para o Brasil, a lógica da intergovernabilidade, na medida em que resguarda a autonomia nacional, permite que o Estado brasileiro mantenha mais capacidade de intervenção nos diferentes processos de integração (Sarti, 2011; Solanas, 2011; Vigevani e Ramanzini Júnior, 2014).

Uma das principais características do atual reordenamento do espaço regional é a heterogeneidade dos diversos regionalismos, que são marcados pela não convergência dos regimes comerciais e pela pluralidade das ideologias. Nos últimos anos, observou-se um relativo deslocamento da América do Sul como subsistema de crescente relevância por suas políticas domésticas e externas de alto perfil, em comparação com as Américas do Norte e Central, que 
mantiveram uma relação de verticalidade com os Estados Unidos. Por um lado, há alianças mais ou menos incondicionais entre o Norte e o Sul, expressas pelos tratados de livre comércio, pelo Nafta e pela Aliança do Pacífico. Por outro, novas configurações Sul-Sul questionam, com diferentes graus, as assimetrias econômicas e políticas do sistema internacional. Entre as organizações que adotam um regionalismo pós-liberal, destacam-se a Alba, a Celac e a Unasul (Lima, 2013; Pecequilo, 2013; Preciado, 2008). Em seguida, serão analisados os diferentes esquemas de regionalismo, enfatizando suas implicações políticas e econômicas.

Com o fracasso da Alca, houve uma proliferação de acordos bilaterais de livre comércio, gerando um ambiente adverso para projetos de integração regional ou sub-regional. Muitos analistas advertem que os tratados de livre comércio reduzem a margem de manobra dos países, impedindo o uso de instrumentos e políticas que poderiam ser utilizadas para seu desenvolvimento. Esses acordos avançam em temas como liberalização de investimentos, compras governamentais, desregulamentação da saúde, da educação e do mercado de trabalho, além do fortalecimento dos direitos de propriedade intelectual. Nos últimos anos, os Estados Unidos firmaram acordos com vários países latino-americanos, consolidando o equivalente a uma nova Alca e cercando o Mercosul e a CAN. No seu entorno imediato, surgiu o Tratado de Livre Comércio entre República Dominicana, América Central e Estados Unidos (CAFTA-DR), que entrou em vigor entre 2006 e 2012. No âmbito sul-americano, foram firmados acordos de livre comércio com o Chile, o Peru e a Colômbia. Nos dois últimos casos, os tratados causaram prejuízos imediatos e irreversíveis à CAN, levando a Venezuela a deixar a organização. Em seguida, Bolívia e Equador sinalizaram que gostariam de aderir ao Mercosul, o que exigiria que ambos renunciassem previamente sua vinculação à CAN. Além disso, os norte-americanos ameaçaram assinar um tratado de livre comércio com o Uruguai, que, caso efetivado, significaria um duro golpe para o Mercosul. 
Assim, observa-se que o objetivo político dos Estados Unidos com esses acordos é dificultar as iniciativas sub-regionais de integração na América do Sul (Botelho, 2013; Fairlie, 2012; Preciado, 2008; Sosa, 2013; Souza, 2009).

Desde que integrou o Nafta, o México tem sido absolutamente fiel ao livre cambismo, cujos desdobramentos recentes incluem sua adesão à Aliança do Pacífico e ao TPP. A inflexão do México, que já teve uma política externa autônoma e ativista, limitou suas estratégias de diversificação, reduziu sua influência tradicional e distanciou o país da América Latina. Em balanço dos vinte anos do Nafta, Jorge Castañeda (2014) conclui que o acordo praticamente não cumpriu suas promessas de crescimento econômico, criação de empregos, aumento da produtividade, incremento salarial e redução da imigração. Nesse período, a renda per capita mexicana mal dobrou, enquanto países como Brasil, Chile, Colômbia, Peru e Uruguai tiveram resultado superior. Segundo José Luis Fiori (2014b), entre 2003 e 2012, o crescimento médio anual do PIB brasileiro foi de $3,5 \%$ e o do mexicano de $2,6 \%$, enquanto a participação dos salários na renda chegou a 45\%, no Brasil, e a 29\%, no México. Desse modo, o resultado do modelo mexicano mostrou-se pior do que o de outros países que não tinham ou demoraram a assinar acordos de livre comércio com os Estados Unidos.

A Declaração de Lima, em 29 de abril de 2011, e o Acordo Marco de Antofagasta, em 6 de junho de 2012, deram origem à Aliança do Pacífico, que tem, como fundadores, Chile, Colômbia, Peru e México. As economias desses países estão entre as mais abertas da região e possuem tratados de livre comércio com os Estados Unidos. A Aliança adota um modelo de regionalismo liberal que privilegia temas econômicos e comerciais, e seu objetivo é facilitar a convergência e a consulta mútua entre seus membros para garantir a livre circulação de todos os fatores produtivos: bens, capital, serviços e mão de obra. Ademais, pretende criar sinergias com o dinâmico mercado da Ásia-Pacífico. Em relação ao fluxo de capitais, foi criado o Mercado 
Integrado Latino-Americano (Mila), que almeja integrar as bolsas de seus países e se tornar o maior mercado de valores da América Latina, atraindo principalmente empresas ligadas à produção de commodities e ao setor financeiro. Todavia, observa-se uma baixa complementariedade econômica entre seus membros e uma pauta exportadora concentrada em produtos primários, o que pode comprometer as ambições do novo organismo. Assim, pode-se dizer que a Aliança do Pacífico tem mais importância ideológica do que econômica dentro da América do Sul, e seria quase insignificante politicamente se não integrasse uma pequena parcela do projeto norte-americano de criar a TPP (Cabral, 2013; Chaves, 2013; Fiori, 2014b; Muñoz, 2012).

Apesar de suas bases econômicas, alguns analistas consideram que a Aliança do Pacífico esconde interesses geopolíticos e possui a intenção de fazer frente ao regionalismo pós-liberal. O bloco seria ao mesmo tempo uma ponte para o Nafta e um contraponto à Alba, ao Mercosul e ao Brasil. Entre as repercussões geopolíticas da Aliança do Pacífico, destacam-se o reforço da presença estadunidense na América do Sul por intermédio do México e a diminuição do protagonismo de Brasil e Venezuela. Adicionalmente, o acordo poderia servir de instrumento para apoiar aliados norte-americanos como o Chile e a Colômbia. Setores do establishment estadunidense consideram a Aliança do Pacífico mais pragmática e menos ideológica do que a "ameaça bolivariana" representada pela Alba. Em relação ao Mercosul, a presença de Paraguai e Uruguai entre os membros observadores da organização indica seu potencial de clivagem e fragmentação. Ademais, a Aliança do Pacífico coloca pressão no Brasil para superar os entraves do Mercosul. Assim, vislumbra-se uma tendência à bifurcação da América Latina em dois eixos: o do Pacífico, que retoma a agenda de livre comércio e adota políticas externas alinhadas aos Estados Unidos; e o do Atlântico, com modelos econômicos mais intervencionistas e políticas exteriores autônomas (Ayerbe, 2014; Cabral, 2013; Chaves, 2013; Falconí, 2014; Lima, 2013; Muñoz, 2012; Rodriguez, 2014; Vigevani e Ramanzini Júnior, 2014). 
A Alba é uma iniciativa do ex-presidente venezuelano Hugo Chávez e foi lançada em contraposição à Alca, em 2004. Pertencem à organização Antígua e Barbuda, Bolívia, Cuba, Dominica, Equador, Nicarágua, São Vicente e Granadinas e Venezuela. A Alba tem caráter prioritariamente político e propõe desenvolver uma integração solidária, buscando o bem-estar dos povos e a defesa do comércio justo e do desenvolvimento sustentável. A identidade da organização baseia-se na afinidade ideológica entre seus membros. Ao estruturar um eixo político-ideológico, a Alba representa um projeto claramente anti-hegemônico e anti-imperialista. Trata-se de uma proposta conflitante com a Aliança do Pacífico, mas que é transversal à Unasul. De fato, a Alba pode existir paralelamente à Unasul, pois cumpre funções diferentes e, ao mesmo tempo, complementares. Ao servir de plataforma para o protagonismo venezuelano, permite à Unasul seguir com seu ritmo gradual e sua busca pelo consenso na região (Botelho, 2013; Carrión Mena, 2013; Preciado, 2008; Saraiva, 2010).

Em 2011, a criação da Celac constituiu um passo importante na busca de maior integração da região para enfrentar problemas comuns. O objetivo é servir como espaço de consulta e concerto político da América Latina, estabelecendo uma interlocução mais equilibrada com os Estados Unidos. A organização é resultado da convergência gradual entre o Grupo do Rio $^{19}$ e a Cúpula América Latina-Caribe. Alguns analistas consideram que o novo organismo poderia eventualmente substituir a OEA, enquanto outros acham que a OEA continuará sendo importante para tratar de temas que envolvam todos os países das Américas, incluindo o Canadá e os Estados Unidos, ausentes da Celac. Assim, a formação da Celac, que

\footnotetext{
${ }_{19}$ O Grupo do Rio foi criado em 1986 como mecanismo permanente de consulta e de concertação política na América Latina e no Caribe. $\mathrm{O}$ fórum surgiu a partir da fusão entre o Grupo de Contadora (Colômbia, México, Panamá e Venezuela) e o Grupo de Apoio à Contadora (Argentina, Brasil, Peru e Uruguai), que buscavam uma solução negociada e pacífica para a crise centro-americana dos anos 1980. Por ser um mecanismo político exclusivamente latino-americano, o Grupo do Rio foi poucas vezes objeto da atenção de estudiosos da integração (Moura, 1990; Saraiva, 2010).
} 
contou com decisivo apoio brasileiro e venezuelano, é uma tentativa de ampliar os limites da cooperação regional para além da América do Sul, contribuindo para recriar a ideia de América Latina em um contexto de crescente heterogeneidade (Borda, 2012; Lima, 2013; Martins, 2011; Simões, 2010; Sosa, 2013).

A Unasul tem um perfil diferente das outras iniciativas e se aproxima mais de um instrumento de governança regional do que dos padrões clássicos de integração. Além disso, percorreu o caminho inverso ao de blocos que somente adquiriram uma dimensão política após consolidarem a comercial. Trata-se de um espaço multilateral de coordenação e cooperação política interestatal que difere dos esquemas de integração convencionais. Nesse sentido, a organização representa a vertente política do novo regionalismo, que absorve demandas econômicas, mas que ultrapassa essa esfera. Todavia, a incipiência de sua atuação em matéria comercial não significa a inexistência de uma dimensão econômica própria. Ao contrário, na Unasul, os objetivos econômicos estão diretamente ligados às iniciativas políticas, voltadas para o incremento da autonomia e da estabilidade institucional de seus membros. Por não ser um regime comercial, a Unasul não compete nem pretende substituir nenhum dos regimes existentes, mas permite que os diferentes países possam cooperar em diversos campos: energético, militar, social, logístico e de infraestrutura. Dessa forma, ela atua como mecanismo de construção de consensos, acomodando distintas visões sobre integração (Amorim, 2009; Borda, 2012; Lima, 2013; Meunier e Medeiros, 2013; Nafalski, 2011; Saraiva, 2010).

No interior da Unasul, coexistem a Alba, o Mercosul e a Aliança do Pacífico. Enquanto os agrupamentos bolivariano e Atlântico são partidários de um projeto de desenvolvimento crítico ao liberalismo e mais voltado para a integração endógena sul-americana, o eixo do Pacífico possui uma nítida coloração neoliberal e está orientado ao mercado mundial. Essa diversidade é parte integrante do contexto heterogêneo no qual foi criada a Unasul. 
A fim de acomodar a pluralidade ideológica do subcontinente, o discurso geopolítico dessa União não recorre ao enfoque anti-hegemônico da Alba, nem à complacência da Aliança do Pacífico, mas enfatiza a autonomia política regional e a necessidade de projetar geopoliticamente a América do Sul. Nesse sentido, o convívio entre diferentes visões da integração, que em muitos casos se sobrepõem, ressalta a importância de se pensar na possibilidade de múltiplos níveis de regionalismo. Ademais, deve-se destacar que a política externa brasileira tem atuado visando a construir um consenso entre os países vizinhos, procurando superar crises regionais e buscando ocupar um papel central no âmbito da Unasul (Preciado, 2008; Saraiva, 2010; Sosa, 2013).

Em resumo, nesta seção observou-se o longo percurso do Brasil e dos países sul-americanos em busca da superação de suas rivalidades e da criação de mecanismos de integração regional. No século XX, o Brasil procurou articular um eixo no Cone Sul, mas as primeiras tentativas de construir um espaço latino-americano integrado só surgiram a partir da década de 1960. Com a redemocratização, a aproximação entre Brasil e Argentina resultou na criação do Mercosul. Nos anos 1990, os governos da América Latina convergiram em torno das ideias neoliberais e da Alca. Com a vitória dos governos progressistas, os cenários homogeneizantes cederam lugar à heterogeneidade das formas de regionalismo. A tratativa entre os países sul-americanos visando a criar um bloco regional conta com decisiva participação brasileira e é percebida com desconfiança pela política externa estadunidense. Entre as novas organizações, destaca-se a Unasul, que possui uma nítida dimensão política. $\mathrm{Na}$ atual conjuntura, cabe ao Brasil desenvolver uma estratégia política e econômica que possibilite a articulação desse bloco sul-americano, desde que ele seja articulado em termos não hegemônicos e leve em consideração as assimetrias existentes no subcontinente. No início do século XXI, os objetivos estratégicos brasileiros tornaram-se entrelaçados com a cooperação na América do Sul, destacando-se a 
necessidade de consolidar uma polaridade sul-americana autônoma no sistema internacional.

\subsection{Unasul: um projeto político para a região}

A Unasul representa uma tentativa inédita de articulação política de todos os países da América do Sul. A ênfase na dimensão política está relacionada com a necessidade de afirmação da autonomia, objetivo presente em diversos momentos históricos dos países sul-americanos. A fim de compreender o ineditismo representado pela Unasul, esta seção analisará seu processo de formação, incluindo os principais fatos e documentos que contribuíram para que ela fosse criada. Serão analisadas as etapas que antecederam a constituição da Unasul, sua estrutura institucional e o papel desempenhado por Brasil e Venezuela na consolidação do bloco. Destacar-se-ão as diferentes visões que os países sul-americanos têm dessa União, além das relações que a envolvem e os demais processos integrativos. Ademais, será realizado um breve balanço da atuação da Unasul na região.

A criação da Unasul constitui um dos fatos mais importantes na história do processo de integração da América Latina. No passado, houve tentativas de cooperação ou integração nos planos pan-americano, hispano-americano, latino-americano e sub-regional. Todavia, antes da Unasul, os países da região nunca tinham assinado um tratado ou instrumento jurídico de caráter tão amplo, envolvendo os doze países da América do Sul. Assim, o advento da Unasul significou deixar para trás as sub-regiões ou microssistemas regionais e passar à construção de um macrossistema regional (Amorim, 2009; Botelho, 2013; Rocha Valencia e Morales Ruvalcaba, 2013).

O primeiro passo do Brasil visando a integrar a América do Sul ocorreu com a Alcsa, em 1993, durante a primeira passagem de Celso Amorim à frente do Itamaraty. Devido às pressões dos Estados Unidos, que estavam lançando o Nafta e iniciando as negociações da Alca, a proposta da Alcsa foi abandonada no primeiro mandato de 
Fernando Henrique. Nos anos 1990, a estratégia brasileira objetivava a ampliação do Mercosul e tinha um viés estratégico-energético que incluía projetos de canalização do gás natural de Argentina e Bolívia. A implementação dessa política foi iniciada em 1996, com a celebração dos Acordos de Complementação Econômica (ACE) 35 e 36 no âmbito da Aladi, envolvendo, respectivamente, os eixos Mercosul-Chile e Mercosul-Bolívia. Outro passo importante foi a assinatura do Acordo Marco para criar uma zona de livre comércio entre Mercosul e CAN, em 1998. A ampliação do bloco mercosulino teve continuidade no governo Lula, com a associação do Peru, por meio do ACE-58, e da Colômbia, do Equador e da Venezuela, pelo ACE-59. Assim, o processo que levaria à criação da Unasul estava estruturado nos eixos Brasil-Argentina e Mercosul-CAN (Botelho, 2013; Costa, 2010; Martins, 2011; Rocha Valencia e Morales Ruvalcaba, 2013).

$\mathrm{Na}$ América Latina, até começarem as reuniôes de presidentes sul-americanos, o encontro de cúpula presidencial mais importante ocorria no âmbito do Grupo do Rio. Em entrevista concedida na sede da Unasul, Diego Cardona (2014), chefe de gabinete da Secretaria Geral da organização, afirmou que muitas regras do Grupo do Rio foram incorporadas pela Unasul, como a regra do consenso e a da periodicidade das reunióes presidenciais e de chanceleres. Isso porque, segundo Cardona, alguns diplomatas que atuavam no Grupo do Rio participaram das negociações do Tratado Constitutivo da Unasul.

Com os encontros presidenciais, foi inaugurado um espaço político de diálogo autônomo e específico, envolvendo, além do Mercosul e da CAN, o Chile, a Guiana e o Suriname. Se o discurso empresarial costumava salientar um Chile desenvolvido, diferente da região, e modelo para ela, sua inserção na Comunidade Sul-Americana de Nações (CSN) e, posteriormente, na Unasul abriu novas possibilidades de relacionamento e de construção identitária para o país andino. Para a Guiana e o Suriname, que eram membros da 
Comunidade do Caribe (Caricom) e haviam ficado de fora da Alcsa, o ingresso na Unasul representou a primeira oportunidade de um maior envolvimento político e econômico com os demais países da América do Sul (Meunier e Medeiros, 2013).

$\mathrm{Na}$ I Reunião de Presidentes da América do Sul, convocada por Fernando Henrique Cardoso em 2000, discutiu-se como organizar a convivência cooperativa e coordenada entre os Estados nos setores de comércio, infraestrutura, luta contra drogas ilícitas, informação e tecnologia. Na ocasião, a diplomacia brasileira ora enfatizava a necessidade de fortalecer o Mercosul por razões econômicas, estratégias e geográficas, ora como instrumento para contrabalançar as negociações da Alca. Apesar de não definir os objetivos políticos, o propósito econômico do encontro estava claro: criar uma área de livre comércio entre Mercosul e CAN. No entanto, a decisão mais importante foi a criação da IIRSA, visando à integração física do subcontinente. Em 2002, a II Reunião de Presidentes da América do Sul conferiu especial atenção à IIRSA e tratou a Alca de forma sucinta e sem manifestação de apoio (Botelho, 2013; Costa, 2010; Meunier e Medeiros, 2013; Rocha Valencia e Morales Ruvalcaba, 2013).

Em dezembro de 2004, foi realizada, na cidade de Cusco, a III Reunião de Presidentes da América do Sul, ocasião na qual foi redigido um documento, a Declaração de Cusco, que lançou a CSN, base da futura Unasul. A Declaração de Cusco (CSN, 2004) invoca os líderes da independência sul-americana - Bolívar, Sucre e San Martín - e faz referência à história e aos desafios comuns dos países da região. Há ainda menção a uma identidade sul-americana compartilhada, sustentada por valores comuns. A Declaração de Cusco aponta para a superação do âmbito comercial ao estabelecer entre os objetivos do novo bloco a concertação política e diplomática. Ao longo do texto, mais de uma vez o primeiro item destacado é o político, revelando que o objetivo da CSN não é apenas econômico, mas estratégico. Ademais, a Declaração de Cusco destaca que o desenvolvimento econômico deve passar pelo reconhecimento das assimetrias regionais e pela coesão 
e inclusão social. Da mesma forma que a política externa brasileira de Lula colocou "a política à frente da economia no comportamento internacional do país”, segundo expressão de Maria Regina Soares de Lima, o encontro de Cusco também passou a priorizar os aspectos políticos da integração da América do Sul (Botelho, 2013; CSN, 2004; Nafalski, 2011; Observatório Político Sul-Americano, 2014; Vigevani e Ramanzini Júnior, 2014).

A CSN consolidou-se em torno de três ideias centrais: a concertação e coordenação de políticas exteriores; a convergência entre Mercosul, CAN, Chile, Guiana e Suriname; e a integração física por meio da IIRSA. Entre 2005 e 2007, foram celebradas três cúpulas essenciais na definição dos contornos institucionais e dos objetivos do que se converteria em Unasul. Em 2005, a I Cúpula da CSN, realizada em Brasília, apresentou as primeiras ideias sobre a institucionalidade do novo organismo. Apesar de alguns avanços, essa reunião foi bastante tensa, pois, além da ausência de quatro países - Colômbia, Guiana, Suriname e Uruguai -, houve discordâncias entre Brasil, de um lado, e Argentina e Venezuela, do outro. O presidente Néstor Kirchner esteve no Brasil, mas não participou da cúpula. Antes, Kirchner já não havia comparecido ao lançamento da CSN, em 2004, por considerá-la um instrumento criado pelo Brasil para projetar seu próprio poder. Para Diego Cardona (2014), o governo argentino foi surpreendido pela proposta brasileira de lançar outro elemento aglutinador do processo integrativo - sendo contra a sua criação -, diferente do Mercosul, visto que priorizava o fortalecimento deste. Por fim, o presidente venezuelano Hugo Chávez inviabilizou a assinatura de uma declaração conjunta, pois divergia do Brasil em relação aos propósitos da CSN (Borda, 2012; Botelho, 2013; CSN, 2005; Martins, 2011; Nafalski, 2011).

Na II Cúpula da CSN, realizada em Cochabamba no final de 2006, foram definidos os princípios e os objetivos do novo modelo de integração. Logo no início, a Declaração de Cochabamba (CSN, 2006) ressalta que a construção da CSN deve envolver os âmbitos 
político, social, cultural, econômico, financeiro, ambiental e de infraestrutura. Além de necessária para enfrentar os problemas sociais que afetam a região, a integração sul-americana é percebida como um passo decisivo para alcançar um mundo multipolar. A declaração destaca que a integração almejada deve ter uma identidade própria, pluralista, reconhecendo as distintas concepções políticas de cada país. Isso garantiu a participação de governos com posições ideológicas tão díspares como o colombiano e o venezuelano. $\mathrm{O}$ documento menciona que uma das premissas para a integração é a valorização da identidade sul-americana. Entre os objetivos da CSN, destacam-se a superação das assimetrias, a infraestrutura, a formação de uma cidadania sul-americana e a participação cidadã. No contexto desse encontro, foi realizada uma Cúpula Social pela Integração dos Povos, cujo documento final resultou no Manifesto de Cochabamba, que incluía críticas ao neoliberalismo, exigia a reestruturação da IIRSA e propunha uma visão alternativa da integração regional. Uma evidência da contribuição das organizações populares foi a iniciativa de mudar o nome de CSN para Unasul, mais tarde retomada por Hugo Chávez na Cúpula de Energia (CSN, 2006; Nafalski, 2011; Rocha Valencia, Morales Ruvalcaba, 2013; Serbin, 2013). ${ }^{20}$

O terceiro e último encontro antes da criação da Unasul ocorreu com a I Cúpula Energética Sul-Americana, realizada em Isla Margarita, na Venezuela, em abril de 2007. No encontro, os chefes de Estado decidiram que a CSN, ou Casa, passaria a se chamar Unasul. Essa mudança não foi uma simples troca de nome ou sucessão, pois significou a transformação de um fórum de concertação política em uma organização internacional. Ademais, foram tomadas outras

\footnotetext{
${ }^{20} \mathrm{Na} C S N$, a participação popular ocorria por meio de cúpulas sociais paralelas, realizadas antes da cúpula intergovernamental. No entanto, com a criação da Unasul em 2008, as cúpulas sociais preliminares deixaram de ser convocadas. Apesar de o tratado constitutivo da Unasul se referir à participação cidadã, não foram criados espaços institucionalizados para o exercício desta. Somente em 2012, surgiu, no âmbito da Unasul, um Foro de Participação Cidadã (Serbin, 2013).
} 
medidas relevantes, como a instituição de uma Secretaria Geral com sede em Quito e a criação do Conselho Energético Sul-Americano (CES), que se tornou o primeiro conselho temático da nascente instituição. Assim, ao longo das três reuniões ocorridas, entre 2005 e 2007, foram estabelecidas as diretrizes centrais que possibilitaram a criação da Unasul (Botelho, 2013; Costa, 2010; Rocha Valencia e Morales Ruvalcaba, 2013).

No dia 23 de maio de 2008, foi celebrada em Brasília uma reunião extraordinária entre os líderes sul-americanos, resultando no Tratado Constitutivo da Unasul, que entraria em vigor no dia 11 de março de 2011, após alcançar o número necessário de ratificações. O preâmbulo do tratado faz referência à história compartilhada, aos líderes da independência e à construção de um futuro comum. $\mathrm{O}$ texto está inspirado pelas Declarações de Cusco, Brasília e Cochabamba, e destaca a determinação dos países signatários de construir uma identidade e cidadania sul-americanas, além de desenvolver um espaço regional integrado nas esferas política, econômica, social, ambiental, energética e de infraestrutura. Reafirma-se, com isso, o compromisso de combater a exclusão e as desigualdades sociais e de reduzir as assimetrias. Ademais, o tratado possui um claro viés geopolítico ao enfatizar que a integração é um passo decisivo para fortalecer o multilateralismo e construir um mundo multipolar. Desse modo, o cerne do novo bloco encontra-se na dimensão política e no seu intuito de afirmar a região como um polo essencial do sistema internacional (Botelho, 2013; Martins, 2011; Unasul, 2008).

Entre os objetivos gerais, previstos no artigo 2. do tratado, destacam-se o diálogo político, as políticas sociais, o meio ambiente, a energia, a infraestrutura e o financiamento, deixando de lado o componente comercial. $\mathrm{O}$ artigo $3 .^{\circ}$ elenca os 21 objetivos específicos, que inclui itens que já vinham sendo mencionados desde as primeiras cúpulas presidenciais no início dos anos 2000. O conjunto desses objetivos constitui um discurso que se materializa em um documento de intenções e de direcionamento da integração regional, mas que 
não forma propriamente uma agenda. Um olhar atento ao texto do tratado permite concluir que não há nenhuma cláusula específica sobre questões comerciais, nem alusão às modalidades habituais de integração de mercados - zona de livre comércio ou união aduaneira. Assim, a Unasul foi constituída como uma organização política "guarda-chuva", pois abriga em sua institucionalidade uma série de ações que, somadas, apontam para uma articulação política mínima entre todos os países da América do Sul (Borda, 2012; Botelho, 2013; Costa, 2010; Martins, 2011; Unasul, 2008).

Ao analisar os textos das declarações da CSN e do tratado constitutivo da Unasul, é possível constatar a presença de uma recorrente terminologia identitária. Segundo Isabel Meunier e Marcelo de Almeida Medeiros (2013), a remissão a símbolos históricos sugere a intenção de revestir instrumentos formais de elementos emocionais, o que indica a busca de uma fundamentação para o projeto integracionista desvinculada de cálculos utilitários. Nesse sentido, a amplitude dos objetivos da instituição reforça o desejo de superar a mera integração econômica. Além disso, os autores observam que o argumento identitário se coloca como instrumento para construir um elo entre passado, presente e futuro, uma espécie de ponte que se materializaria na Unasul.

A estrutura institucional da Unasul está prevista no artigo 4. ${ }^{\circ}$ do Tratado Constitutivo e é formada pelos seguintes órgãos: Conselho de Chefas e Chefes de Estado e de Governo, Conselho de Ministras e Ministros das Relações Exteriores, Conselho de Delegadas e Delegados e a Secretaria Geral. O Conselho de Chefas e Chefes de Estado é a instância máxima e de condução política da Unasul. Entre suas competências, destacam-se: estabelecer as diretrizes políticas e o modo como serão implementadas as ações para o processo de integração; convocar reuniões setoriais e criar órgãos de âmbito ministerial; e deliberar sobre as propostas do Conselho de Ministros das Relações Exteriores. O órgão máximo se reúne anualmente, além das reuniões extraordinárias. Ademais, 
conta com uma Presidência Pro Tempore (PPT) que tem, entre suas funções, organizar as reuniões das instâncias da Unasul, representar a organização em eventos internacionais, bem como assumir compromissos e assinar declarações com terceiras partes, desde que autorizada pelos órgãos competentes. A PPT é exercida rotativamente por cada um dos Estados em ordem alfabética durante o período de um ano (Botelho, 2013; Costa, 2010; Unasul, 2008).

O Conselho de Ministras e Ministros das Relações Exteriores é responsável por adotar resoluções para implementar as decisões da instância máxima. Entre suas atribuições, destacam-se: propor projetos e preparar as cúpulas de chefes de Estado; coordenar posições em temas cruciais ao processo integrativo; promover o diálogo político e a concertação sobre assuntos regionais e internacionais; deferir o orçamento anual da instituição; e avaliar os avanços dos objetivos da Unasul. O Conselho tem encontros a cada seis meses, além da possibilidade de reuniões extraordinárias (Botelho, 2013; Costa, 2010; Unasul, 2008).

O Conselho de Delegadas e Delegados é formado por um representante acreditado de cada Estado-membro e é encarregado de implementar, com o apoio da PPT e da Secretaria Geral, os acordos emanados dos órgãos superiores, preparar suas reuniões e elaborar projetos de decisão, resolução e regulamento, submetendo-os à consideração das instâncias superiores. Esse tem sido o órgão mais ativo da Unasul e é responsável por tentar compatibilizar as iniciativas da organização com outros processos de integração regional e sub-regional, além de constituir e coordenar os grupos de trabalho. $\mathrm{O}$ Conselho se reúne com periodicidade preferentemente bimestral (Botelho, 2013; Costa, 2010; Rocha Valencia e Morales Ruvalcaba, 2013; Unasul, 2008).

Por fim, a Secretaria Geral, sediada em Quito, é a instância responsável por executar os mandatos que lhe são conferidos pelos demais órgãos da Unasul e exercer sua representação por delegação expressa deles. Entre as principais instituições, é a única que possui 
sede própria e um corpo de funcionários com dedicação exclusiva. A Secretaria Geral tem autonomia em relação aos Estados-membros e deve prestar contas unicamente à Unasul, uma vez que seus funcionários não solicitam nem recebem instruções de nenhum governo. O secretário geral é designado pelo Conselho de Chefas e Chefes de Estado para um mandato de dois anos, renovável uma única vez, e não pode ser sucedido por uma pessoa da mesma nacionalidade (Botelho, 2013; Costa, 2010; Rocha Valencia e Morales Ruvalcaba, 2013; Unasul, 2008).

A estrutura institucional da Unasul, que tem por finalidade auxiliar e propor políticas públicas para o bloco a partir de suas respectivas áreas, conta também com doze conselhos temáticos que são integrados por ministros vinculados aos respectivos temas e são constituídos por órgãos de assessoramento e estudos, com sede e funcionários próprios, além de grupos de trabalho. Ao estabelecer um arcabouço institucional para ampliar a cooperação regional em diferentes políticas públicas, os conselhos estimulam a participação de diversos atores políticos e econômicos no âmbito de cada país, muitos comprometidos com a regionalização em suas múltiplas facetas (Botelho, 2013; Lima, 2013).

Depois de absorver o CES, criado em 2007, a Unasul criou outros onze conselhos entre 2008 e 2012. Na reunião extraordinária de chefes de Estado ocorrida em Salvador, em 2008, foram criados o Conselho Sul-Americano de Defesa (CDS) e o Conselho de Saúde Sul-Americano (CSS). Uma característica em comum entre eles é que ambos contam com uma instância de assessoramento e estudos: o Centro de Estudos Estratégicos de Defesa (CEED), com sede em Buenos Aires, e o Instituto Sul-Americano de Governo em Saúde (ISAGS), sediado no Rio de Janeiro. Na cúpula de Quito, em 2009, surgiram mais três conselhos: problema mundial das drogas (CSPMD); desenvolvimento social (CSDS); e de infraestrutura e planejamento (COSIPLAN). Nos anos seguintes, foram criados outros conselhos nas seguintes esferas: educação (CSE); cultura 
(CSC); ciência, tecnologia e inovação (COSUCTI); economia e finanças (CSEF); segurança cidadã contra a delinquência organizada transnacional (DOT); e eleitoral (CEU). O Conselho Eleitoral da Unasul, responsável pela organização de missões e pelo intercâmbio de conhecimento na área eleitoral, teve como primeira missão acompanhar o processo eleitoral venezuelano de 2012. Fora da estrutura institucional da Unasul, encontra-se o Banco do Sul, cujo objetivo é realizar investimentos de longo prazo, garantindo à região maior autonomia em relação ao BID e ao Banco Mundial (Botelho, 2013; Costa, 2010; Vigevani e Ramanzini Júnior, 2014).Na figura 4, observa-se o esquema político-institucional geral da Unasul.

\section{Figura 4 - Estrutura organizacional da Unasul}

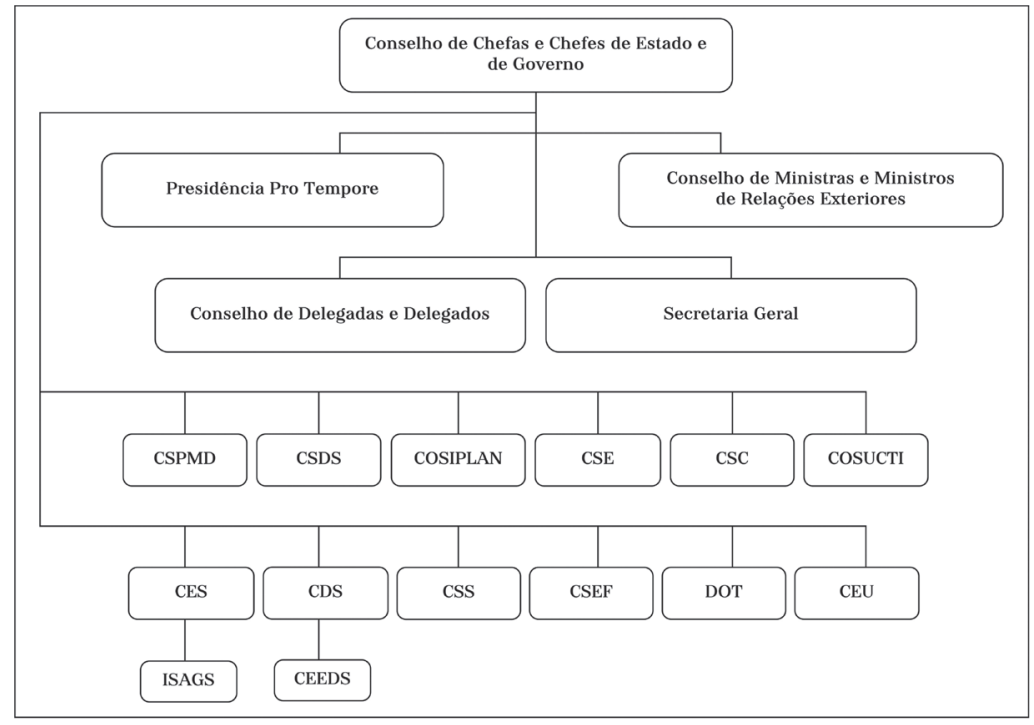

Fonte: $\mathrm{O}$ autor, 2015.

Apesar de não integrar a estrutura da Unasul, a discussão em torno do Banco do Sul merece algumas considerações. A questão do financiamento, por exemplo, tem procurado conectar o tema da 
autonomia nacional com os objetivos de cooperação e integração regional. Todavia, a ideia de criar uma instituição financeira regional sempre dividiu os países sul-americanos. A Venezuela concebia o Banco do Sul como uma alternativa ao FMI e aos bancos de desenvolvimento que atuavam na região. $\mathrm{O}$ novo Banco deveria financiar projetos de desenvolvimento e atuar em momentos de crise especulativa ou de solvência em toda a América Latina. O Brasil, entretanto, questionou a proposta, pois era contrário à ruptura com as instituiçõos financeiras multilaterais existentes. A crítica brasileira, sobretudo do Ministério da Fazenda e do Banco Central, referia-se ao risco da utilização de critérios não rigorosos na administração de instituições regionais de financiamento (Borda, 2012; Botelho, 2013; Vigevani e Ramanzini Júnior, 2014).

Depois um longo processo de negociação, a intenção de criar o Banco do Sul foi oficializada em dezembro de 2007, sem que houvesse um acordo relativo a questões como a participação acionária e o direito de voto de cada Estado membro. Participaram do lançamento do Banco sete (Argentina, Bolívia, Brasil, Equador, Paraguai, Uruguai e Venezuela) dos doze membros da Unasul. Na ocasião, o Brasil conseguiu limitar a atuação do novo organismo, que deveria financiar projetos de desenvolvimento apenas na América do Sul. Em setembro de 2009 foi assinado, com o apoio de Brasil, Argentina, Bolívia, Equador, Paraguai, Uruguai e Venezuela, o convênio constitutivo do Banco do Sul, com sede em Caracas. Uma das motivações que levou o Brasil a apoiar esse Banco está relacionada à impossibilidade de utilização de recursos do BNDES para financiar investimentos de empresas estrangeiras fora do país. $\mathrm{O}$ acordo que criou o Banco do Sul começou a valer em 2012, quando se alcançou, com a ratificação do Uruguai, a quantidade mínima de países e capital necessários para o início de sua vigência. Em 2015, o congresso brasileiro era o único que ainda não havia aprovado o ingresso efetivo do país no Banco do Sul (Borda, 2012; Botelho, 2013; Vigevani e Ramanzini Júnior, 2014). 
Alguns analistas criticam a baixa institucionalização da Unasul, que poderia se tornar um obstáculo à integração e condicionar seu avanço aos governantes de plantão. O caráter intergovernamental da organização é apontado como um entrave. Um exemplo da fraqueza institucional encontra-se no pouco poder atribuído à Secretaria Geral, único órgão que poderia adquirir componentes supranacionais. As atribuições do secretário geral foram reduzidas a níveis meramente administrativos, sem competência política para a adoção de medidas que exijam celeridade e maior representatividade política. Além disso, o mandato de dois anos seria insuficiente para desenvolver um trabalho satisfatório. Para entusiastas da Unasul, como o presidente equatoriano Rafael Correa, a Secretaria Geral deveria ser ocupada por ex-presidentes, como sucedeu com Néstor Kirchner, em 2010, e ocorre atualmente com Ernesto Samper, ex-presidente colombiano (Botelho, 2013; Carrión Mena, 2013). ${ }^{21}$

Nas discussões para a criação da Unasul, houve fortes divergências em relação à estrutura da organização. Enquanto o Brasil, por exemplo, defendia um organismo menos denso, de caráter consensual, o Equador buscava uma maior densidade institucional. Em entrevista, o diplomata equatoriano Jorge Acosta Arias (2014) afirmou que o Brasil tem defendido que a Unasul se limite a atuar como um foro político, diferentemente do Equador, que apoia uma maior institucionalização e o incremento das outras dimensões do bloco. Essa divergência demonstra que, para a política externa brasileira, a integração só é interessante caso garanta flexibilidade à atuação do país e não inviabilize as possibilidades de projeção global.

\footnotetext{
${ }^{21}$ Após a frustrada designação do ex-presidente equatoriano Rodrigo Borja e da interrompida gestão de Kirchner, cuja eleição havia sido questionada pelo Uruguai, a eleição do secretário geral foi complexa e resolvida por um acordo. Com a morte do ex-presidente argentino e diante do impasse entre as candidaturas de Colômbia e Venezuela, o Brasil fez uso de sua influência para que ambos dividissem o período de dois anos, correspondendo o primeiro ano à colombiana María Emma Mejía e o segundo ao venezuelano Alí Rodríguez (Carrión Mena, 2013).
} 
A criação da Unasul representou uma mudança nas concepções de Brasil e Venezuela sobre o alcance temático e territorial da integração. Os incentivos econômicos não são suficientes para explicar o surgimento da Unasul e precisam ser combinados com os objetivos políticos dos governos. No caso brasileiro, a ideia de superar a dimensão comercial foi fortalecida com a chegada de Lula ao poder. Além da atuação do presidente, a política externa brasileira contou com formuladores importantes, como Celso Amorim, Samuel Pinheiro Guimarães e Marco Aurélio Garcia. Enquanto Amorim sempre reiterou a dimensão econômica como ponto fundamental para alcançar a unidade política, Guimarães e Garcia apostaram em um processo político que pudesse resultar em ganhos de autonomia, econômicos e sociais para a região. No caso venezuelano, a ascensão de Hugo Chávez trouxe mudanças à política externa do país, que passou a incorporar uma visão geopolítica e a priorizar a integração regional, enfatizando sua dimensão política. Assim, o principal fator para o surgimento da Unasul foi a atuação dos governos Lula e Chávez, que lograram superar obstáculos históricos à integração e aproveitar o contexto regional e internacional favorável ao avanço do processo (Botelho, 2013; Costa, 2010).

O Brasil e a Venezuela coincidem sobre a necessidade de um perfil político para o novo regionalismo, que deve ser um instrumento para políticas de desenvolvimento distributivas e contribuir para a projeção internacional sul-americana. No entanto, ambos divergem sobre os meios para alcançar tal desiderato. Os contrastes são demarcados pelas estratégias de cada país. Por um lado, a estratégia venezuelana baseia-se em uma visão geoestratégica e militar, marcada pela retórica inflamada de Chávez e Maduro. A política externa venezuelana caracteriza-se pelo caráter confrontacional e antagônico em relação aos Estados Unidos. Ademais, sua concepção da Unasul é a de uma organização que se aproxima do ideário bolivariano. Por outro, a estratégia brasileira é multidimensional e se apoia no desenvolvimento comercial e produtivo. A moderação 
da diplomacia brasileira é explicada pela aspiração do país em converter-se num ator de referência global a partir da afirmação de sua liderança na região. Por isso, o Brasil busca uma convivência harmônica com os Estados Unidos e não concebe a Unasul como um organismo anti-imperialista. Apesar das diferenças, as duas estratégias possuem uma visão multipolar do mundo (Borda, 2012; Botelho, 2013; Serbin, 2009, 2011; Vilosio, 2010).

Alguns autores afirmam que Brasil e Venezuela competem pela liderança na América do Sul. Para outros, não há competição, apenas projetos com visões geopolíticas e econômicas distintas. Com uma política externa com baixa institucionalização e pouco pragmática, a liderança venezuelana apoiou-se até recentemente na utilização do petróleo para construir alianças e conquistar apoios. Já o Brasil não tem demonstrado interesse em exercer de forma plena a liderança, pois busca fortalecer sua presença global unilateralmente, sem assumir uma representação regional (Carrión Mena, 2013; Malamud, 2009; Martins, 2011). Em entrevista, o ex-chanceler Francisco Carrión Mena (2014) afirmou que a liderança da Unasul deveria caber ao Brasil, o que não ocorre na realidade. Segundo ele, Lula era um entusiasta da integração sul-americana, o que não pode ser dito da presidenta Dilma, que pouco viajou para os países da região. Na mesma direção, Jorge Acosta Arias (2014) afirmou que o Brasil não tem apoiado decididamente o projeto da Unasul, que poderia ter avançado muito mais, caso houvesse mais vontade política por parte da diplomacia brasileira. Diante dessas divergências, Luis Fernando Ayerbe (2014) observa que alguns think tanks estadunidenses propõem que os Estados Unidos trabalhem na construção de alianças que explorem as diferenças entre as lideranças da Venezuela e do Brasil.

As divergências entre os países da Unasul envolvem também questões relativas à concepção de determinados órgãos e à relação entre o organismo e outras instituições. A criação do CDS envolveu um amplo debate entre os líderes. Inicialmente, Chávez havia proposto uma institucionalidade de segurança coletiva dotada de 
orçamento próprio, uma espécie de aliança político-militar. Essa sugestão foi habilmente substituída pela proposta brasileira de criar um conselho no âmbito da Unasul, cujo objetivo seria incentivar a prevenção e a resolução de conflitos. Em realidade, o CDS deveria funcionar como um fórum para promover o diálogo e a cooperação entre os Ministérios da Defesa de cada país. O ineditismo geopolítico do CDS resulta do fato de ser um arranjo de defesa exclusivamente sul-americano, rompendo com o histórico de instituições hemisféricas tuteladas pelos Estados Unidos. Ao se estabelecer como instância permanente da Unasul, o CDS representa a apropriação pela região dos problemas relativos à defesa, antes tratados de maneira descoordenada e com envolvimento de potências externas (Costa, 2010; Lima, 2013; Serbin, 2009, 2011; Simões, 2010).

A tensão com outras organizações internacionais é mais explícita em relação à OEA, cuja agenda política é similar à da Unasul. Alguns especialistas acreditam que a criação de instituições regionais próprias representa uma reação crítica a entidades tradicionais, como a OEA, que poderia ser substituída pela Unasul na resolução de conflitos regionais. João Carlos Parkinson (2014) afirmou, em entrevista, que atualmente a OEA não estaria respondendo à realidade e às expectativas sul-americanas. Todavia, seu enfraquecimento prejudica o diálogo entre a América do Sul e os Estados Unidos. Segundo o diplomata, essa situação só poderia ser revertida se os norte-americanos se empenhassem em atualizar sua política hemisférica e reformassem a organização. No mesmo sentido, certos analistas afirmam que a perda de importância da OEA reflete o descolamento da política dos Estados Unidos para a região, ressaltando, contudo, que essa mudança não é homogênea entre os países da América Latina. No caso do México, por exemplo, a proximidade geográfica e a interdependência econômica fazem da OEA um espaço multilateral importante em sua relação com os Estados Unidos. No âmbito da Unasul, enquanto alguns países veem o organismo como um entre múltiplos tabuleiros, como a Colômbia, outros simplesmente o enxergam como um foro que poderá 
contribuir para debilitar a OEA, a exemplo de Equador e Venezuela (Borda, 2012; Lima, 2013; Muñoz, 2012; Vilosio, 2010). Todavia, a melhor maneira de verificar se houve perda de influência por parte da OEA é analisar a intervenção da Unasul em algumas crises regionais.

A intervenção da Unasul na crise boliviana de 2008 confirmou a crescente autonomia dos países sul-americanos na resolução dos seus conflitos. A crise começou quando os departamentos bolivianos mais ricos se insurgiram contra medidas do governo Morales que modificavam a repartição dos impostos relativos ao petróleo e ao gás. $\mathrm{Na}$ ocasião, o governo brasileiro impôs três condições para a intervenção da Unasul, cujos membros se encontravam reunidos em Santiago: a) que a intervenção fosse convocada pelo governo eleito democraticamente da Bolívia; b) que buscasse consolidar a institucionalidade vigente e promovesse o diálogo entre as partes em conflito; c) que evitasse qualquer referência ao papel dos Estados Unidos. Essa última posição causou divergências entre Brasil e Venezuela, pois Chávez defendia que os Estados Unidos fossem denunciados. Na Declaração de La Moneda, os presidentes sul-americanos manifestaram apoio ao colega boliviano, rechaçaram os atos violentos e advertiram que não reconheceriam um governo originado de um golpe de Estado ou ação separatista. Em 2010, a Unasul reagiu energicamente à tentativa golpista contra o governo de Rafael Correa, resultando pouco depois na elaboração de uma cláusula democrática sob a forma de um Protocolo Adicional ao seu Tratado Constitutivo. Em 2012, a deposição do presidente paraguaio Fernando Lugo levou, pela primeira vez, à aplicação da cláusula democrática e à consequente suspensão do Paraguai do bloco. O conjunto dessas atuações da Unasul revelou o progressivo enfraquecimento da OEA como organismo encarregado de contribuir para a solução pacífica e a mediação das crises regionais envolvendo os países sul-americanos (Botelho, 2013; Rocha Valencia e Morales Ruvalcaba, 2013; Serbin, 2009 e 2011). ${ }^{22}$

${ }^{22}$ A cláusula democrática da Unasul possui duas características que a tornam mais legítima do que a Carta Democrática interamericana da OEA. Em primeiro 
A Unasul é uma organização para onde convergem, em maior ou menor medida, diferentes tipos de interesses dos Estados-membros. O embaixador Fernando Simas (2014) afirmou em entrevista que a imagem da Unasul é aproveitada de diversas maneiras por cada integrante. Os países da Alba, por exemplo, veem a organização de um modo diferente de Brasil e Argentina, que a concebem como uma espécie de extensão do Mercosul. De acordo com Diego Cardona (2014), todos os países querem construir a Unasul, mas não necessariamente da mesma forma e no mesmo ritmo. O Chile e o Peru entendem que a inserção sul-americana é tão importante quanto a relação com o eixo Ásia-Pacífico. Já a Colômbia percebe a Unasul como um instrumento para equilibrar suas relações com os Estados Unidos e outros governos da região. Segundo João Carlos Amoroso Botelho (2013), a importância da Unasul para a Venezuela é mais política do que econômica, apesar de sua economia depender bastante do comércio regional. Para o Brasil, o bloco apresenta um caráter tanto político, devido à prioridade das relações com o entorno, quanto econômico, como consequência da importância das exportações regionais para setores-chave da economia brasileira, como a indústria. Assim, cada país tem suas próprias razões geopolíticas e econômicas para defender a construção da Unasul.

A América do Sul não é um espaço uniforme, pois sempre se caracterizou como uma região heterogênea, diversa e desigual que, apesar de afinidades históricas, nunca se constituiu em um bloco com interesses similares. Segundo Lima (2013), a lente conceitual para uma adequada análise do novo regionalismo sul-americano deve ser a da diversidade e da heterogeneidade, e não a da fragmentação. Diferentemente do Mercosul, a Unasul surgiu em um

lugar, sua aplicação não levanta a suspeita de estar sendo usada como justificativa para a intervenção, como fizeram os Estados Unidos muitas vezes ao longo da história. Em segundo, o compromisso da OEA é exclusivamente com a democracia representativa, enquanto a cláusula da Unasul evita o uso desse adjetivo (Borda, 2012). 
contexto de diversidades regionais. Em seu interior, coexistem três agrupamentos - o bolivariano, o Atlântico e o Pacífico - que contam com diferentes propostas de integração econômica e orientações ideológicas distintas. Ademais, os governos de esquerda foram fundamentais para a construção da Unasul. Diante dessa realidade, é possível colocar duas perguntas sobre o futuro da organização: a Unasul poderia se converter em uma espécie de mínimo denominador comum dos diversos projetos de integração sul-americanos? A organização sobreviveria a uma mudança da conjuntura política, com o fim do ciclo de governos progressistas?

Essas perguntas foram respondidas de maneiras diversas pelos entrevistados, com convergências e divergências. Em relação à primeira pergunta, Fernando Simas (2014) não considera a Unasul um mínimo denominador comum. Se há possibilidades de convergência no âmbito dos conselhos setoriais, de caráter mais técnico, o mesmo não ocorre nas questões comerciais. Portanto, no curto prazo, o embaixador não acredita que a Unasul possa se transformar em um espaço de convergência entre os diferentes regimes comerciais. Para Jorge Acosta Arias (2014), a Unasul não necessariamente pode se tornar um mínimo denominador dos processos de integração. No momento, o principal desafio da organização é garantir a representatividade dos esquemas sub-regionais, respeitando a dinâmica de cada um deles. No entanto, Arias vê com ceticismo um possível entendimento entre a Unasul e a Aliança do Pacífico, classificada por ele como a nova expressão política da Alca.

Por sua vez, Francisco Carrión Mena (2014) acredita que a Unasul pode se projetar politicamente em questões afins, em temas relacionados, por exemplo, à defesa e à segurança. No mesmo sentido, o diplomata João Carlos Parkinson (2014) considera que a Unasul tem potencial para se tornar um mínimo denominador na América do Sul. Ele citou o papel do Cosiplan, pois o tema da infraestrutura seria uma agenda positiva e interessaria a todos os projetos de integração contidos na Unasul. Por fim, Diego Car- 
dona (2014) acha que o principal desafio da Unasul é trabalhar com os elementos comuns de cada um dos modelos de integração existentes na região; isso é parte da dificuldade do bloco, que tem de administrar as diferenças em seu interior. Ele não considera que a Aliança do Pacífico seja um modelo geopolítico alternativo ou em oposição à Unasul. Segundo o analista, tanto a presidente chilena Michele Bachelet quanto o ex-presidente Lula têm contribuído para o diálogo entre a Aliança do Pacífico e o Mercosul no âmbito da Unasul. Atualmente, Cardona afirmou que a Unasul está empenhada em realizar seminários e estimular reflexões entre acadêmicos e burocratas para debater a melhor forma de compatibilizar os três processos integrativos.

Quanto à segunda pergunta, Botelho (2013) teme que o modelo interpresidencialista possa contribuir para o fracasso ou a extinção da Unasul caso haja a eleição de governos que decidam pelo fim da organização, sobretudo no Brasil, na Argentina e na Venezuela. Todavia, Fernando Simas (2014) não acredita que a Unasul venha a desaparecer com a mudança na orientação ideológica dos governos, pois a organização tem propiciado um espaço regional de mediação e acomodação de diferentes interesses e visões de mundo. Diego Cardona (2014) compartilha a mesma opinião do embaixador. Segundo ele, a continuidade da organização exige que os governos e as oposições da região compreendam que um processo de integração como a Unasul não pode depender apenas de afinidades ideológicas, pois os temas de longo prazo ultrapassam as diferenças partidárias.

Em resumo, desde que foi criada, a Unasul tem se consolidado como uma instância para a negociação de crises regionais. Trata-se de um fórum de coordenação que representa a vertente política e a principal expressão do novo regionalismo sul-americano. Sem desconhecer as diferenças entre seus membros, a instituição tem trabalhado para superá-las, mantendo um espaço permanente de interlocução. Em seu interior, coexistem distintas 
visões da América do Sul, e a estrutura institucional da organização tem servido de ponte entre o discurso sul-americanista comum e os vários discursos baseados nos interesses nacionais. A Unasul representa o coroamento de um processo de afirmação de uma identidade sul-americana possível contra a pulverização histórica das nações da região. Ademais, a Unasul vem exercendo um importante papel geopolítico e geoeconômico, pois tem garantido mais autonomia regional e contribuído para a formação de um polo sul-americano.

\subsection{Síntese do capítulo}

$\mathrm{Na}$ primeira seção, foram analisadas as transformações geopolíticas que vêm ocorrendo nos últimos anos e o modo como os países do Sul têm buscado se articular no sistema internacional, destacando-se o lugar do Brasil e da América do Sul na nova geografia do poder mundial. Inicialmente, foram revisitadas algumas contribuições da geopolítica clássica. Em seguida, passou-se à análise do BRICS, que constitui a principal coalizão do novo ativismo do Sul global. Apesar das diferenças e das contradições entre seus membros, o BRICS serve de contrapeso à influência das grandes potências. No entanto, observou-se que o declínio relativo dos Estados Unidos não diminuiu sua influência global. No âmbito latino-americano, a América do Sul possui maior relevância geopolítica para os Estados Unidos, devido ao seu enorme potencial econômico e político. O aumento da pressão competitiva mundial já incorporou o subcontinente, cujos recursos naturais têm sido objeto de disputa, principalmente entre chineses e norte-americanos. Do ponto de vista político, o principal objetivo dos Estados Unidos sempre foi impedir o surgimento de um polo de poder na América do Sul. Nos últimos anos, a vitória de governos progressistas e o aumento da projeção internacional do Brasil contribuíram para a articulação de um bloco sul-americano mais autônomo. 
A segunda seção analisa a maneira como a política exterior do Brasil procurou superar as rivalidades históricas e promover maior aproximação com os demais países sul-americanos. No início do século passado, houve tentativas do Brasil em criar um eixo no Cone Sul, porém as iniciativas mais ambiciosas de institucionalizar a integração só ocorreriam nos anos 1960. Com a redemocratização, formou-se um eixo político e econômico entre Brasil e Argentina que culminaria na formação do Mercosul. Nos anos 1990, a América Latina atravessou um momento de homogeneização forçada, com a ascensão de governos conservadores, a adoção de políticas econômicas neoliberais e uma inserção internacional subordinada ao projeto hemisférico dos Estados Unidos. Nos anos 2000, a reorientação da política externa estadunidense e a crise do neoliberalismo possibilitaram a vitória de governos progressistas na América do Sul, que promoveram a construção de instrumentos regionais próprios, marcados pela diversidade e dotados de mais autonomia diante de Washington. Entre as novas organizações, a Unasul possui um perfil diferente, pois foi criada como um fórum político de coordenação e cooperação, e não como um mecanismo tradicional de integração econômica. Em seu interior, coexistem governos com posiçôes ideológicas distintas e diferentes regimes comerciais. Assim, o conjunto dessas características faz da Unasul um possível mínimo denominador comum regional, que tenta contribuir para a consolidação de uma polaridade sul-americana autônoma no sistema internacional.

$\mathrm{Na}$ terceira e última seção, procurou-se analisar o processo de criação da Unasul, suas características institucionais, seu relacionamento com outros organismos e o papel de Brasil e Venezuela na sua construção. A trajetória que levou ao surgimento da Unasul foi resultado de um projeto estratégico do Brasil visando a construir um espaço regional integrado. Inicialmente voltado para a integração comercial e da infraestrutura, o projeto somente adquiriria uma conotação política com a ascensão dos governos progressistas. Entre as principais características da Unasul, destacam-se o plura- 
lismo ideológico de seus membros e o caráter multidimensional da organização, que permite a cooperação em diversas áreas de políticas públicas. Com a Unasul, a região adquiriu mais autonomia para resolver seus próprios problemas, provocando a perda relativa de importância de organizações como a OEA. De fato, a Unasul parece ter se consolidado como uma instância de negociação das crises regionais.

Apesar de alguns analistas não estarem convencidos da sua viabilidade e eficácia, a Unasul vem abrindo espaços, resistindo a ceticismos e superando obstáculos. Em que pese certas debilidades, a organização tem contribuído para uma maior autonomização da região no sistema mundial. Certamente, sua existência não é vista com simpatia pelos Estados Unidos, pois a Unasul é a tentativa de materializar um polo sul-americano sempre temido e evitado pela política externa norte-americana. O sucesso da Unasul, portanto, precisa ser medido por uma visão estratégica de longo prazo, e não pela fotografia imediata.

Certa vez, um dos mais originais pensadores latino-americanos, o peruano José Carlos Mariátegui (2005, p. 120), escreveu: "Não queremos, certamente, que o socialismo na América seja decalque e cópia. Deve ser criação heroica. Temos de dar vida, com nossa própria realidade, na nossa própria linguagem, ao socialismo indo-americano. Eis uma missão digna de uma geração nova”. A América Latina já deu mostras de originalidade com a CEPAL, a teoria da dependência e a teologia da libertação. No momento, um dos principais desafios dos intelectuais e dos povos da região é aprofundar a reflexão sobre o novo regionalismo. 